NBER WORKING PAPER SERIES

\title{
HI-TECH INNOVATION AND PRODUCTIVITY GROWTH: DOES SUPPLY CREATE ITS OWN DEMAND?
}

\author{
Robert J. Gordon \\ Working Paper 9437 \\ http://www.nber.org/papers/w9437 \\ NATIONAL BUREAU OF ECONOMIC RESEARCH \\ 1050 Massachusetts Avenue \\ Cambridge, MA 02138 \\ January 2003
}

This research has been supported by the National Science Foundation. I am grateful to Henry Chen for creating the figures, to John Haltiwanger and Jack Triplett for helpful discussions, to Daniel Sichel for providing his latest data as summarized in Table 4, and to William Nordhaus for an updated version of his stock market spread data. The views expressed herein are those of the authors and not necessarily those of the National Bureau of Economic Research.

(C)2003 by Robert J. Gordon. All rights reserved. Short sections of text not to exceed two paragraphs, may be quoted without explicit permission provided that full credit including . notice, is given to the source. 
Hi-tech Innovation and Productivity Growth: Does Supply Create Its Own Demand?

Robert J. Gordon

NBER Working Paper No. 9437

January 2003

JEL No. E00, O30, O40

\section{ABSTRACT}

This paper argues that the late 1990s boom in ICT investment was unsustainable for both macro and micro reasons; we are unlikely again to witness an interval in which computer hardware investment grows at an annual rate greater than 30 percent for five straight years. Analysts who base their optimism on the role of Moore's Law in creating endless exponential growth of computer power neglect the need for an equally rapid explosion in the demand for computer power. Simply put, this paper argues that supply does not create its own demand

Yet a failure of ICT investment to revive to the ebullient growth performance of the late 1990s does not doom productivity growth to slip back to the dismal pre-1995 era. Instead, we argue that conventional analyses have exaggerated the contribution of ICT investment to the post-1995 productivity performance. Productivity can continue to grow at respectable rates even if ICT investment continues to slump. While accepting the contribution of ICT production to economy-wide productivity growth, the paper cites four reasons to suspect that standard analyses have exaggerated the contribution of ICT use, the so-called "capital deepening" effect. First, these analyses unrealistically assume that the productivity payoff of computer use is instantaneous upon installation. Second, recent research indicates that the strong revival of productivity growth in retail trade occurred for reasons other than ICT use. Third, differential productivity growth across states in the U. S. appears to be related to ICT production but not to ICT use. Fourth, retailers in Europe use the same ICT equipment as in the U. S. yet have failed to enjoy a productivity revival, again indicating that factors other than ICT use are central.

The core of the paper is to show that while exponential increases in the supply of computer power are ongoing, the growth in demand for that power was unsustainably high in the late 1990s. The macro environment fostering ICT investment included the stock market bubble, as well as temporary factors that held down the inflation rate and allowed the Fed to pursue a monetary policy of benign neglect. The micro environment featured numerous factors that boosted the demand for ICT investment in the late 1990s only temporarily, including the telecom bubble, the fact that the web could only be invented once, the legacy of the failed dotcoms, and the little-noticed fact that software innovation has fallen badly behind the pace of hardware innovation.

Robert J. Gordon

Department of Economics

Northwestern University

Evanston IL 60208-2600

and NBER

rjg@northwestern.edu 


\section{TABLE OF CONTENTS}

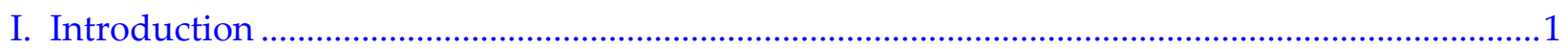

Productivity Growth and ICT Investment......................................................................

Macro: The Positive Feedback Loop ................................................................................

Micro: The Unsustainable Demand for ICT Equipment in the Late 1990s .........................3

II. Dimensions of the Post-1995 Productivity Growth Revival .......................................................5

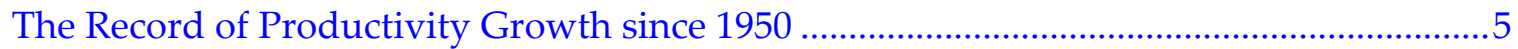

Cyclical Dimensions of Productivity Growth .............................................................

III. The Contribution of Hi-Tech Investment to the Productivity Growth Revival .......................9

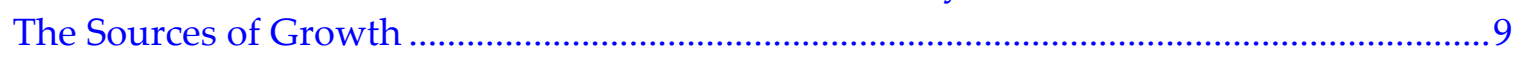

Has the Contribution of Hi-tech Investment been Exaggerated? ........................................11

IV. The Puzzling Contrast between the United States and Europe..............................................14

V. Positive Feedback Loops among the ICT Investment Boom, the Stock Market,

Low Inflation, and Monetary Policy ................................................................................. 19

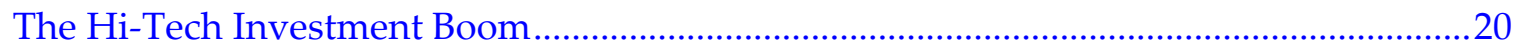

Pillar of the Postive-feedback Loop: the Stock Market .......................................................22

Low Inflation Enabled Easy Monetary Policy .......................................................................27

VI. The Interplay of Supply and Demand in the ICT Investment Boom ......................................31

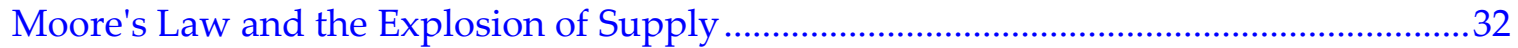

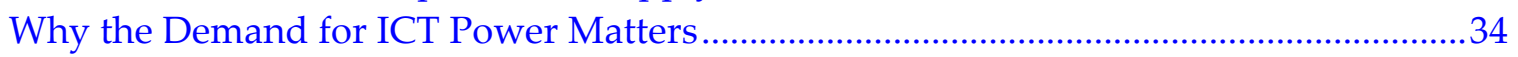

VII. Unsustainable Sources of Demand for ICT Investment in the Late 1990s............................37

The Telecom Equipment Bubble and Meltdown ....................................................................

Differences between Computer and Telecom Investment ....................................................39

The Web could be Invented Only Once ................................................................................ 40

Legacy of the Failed Dotcoms......................................................................................... 41

Software Innovation is Falling behind Hardware Innovation ............................................... 43

Y2K Compressed the Replacement Cycle .......................................................................... 46

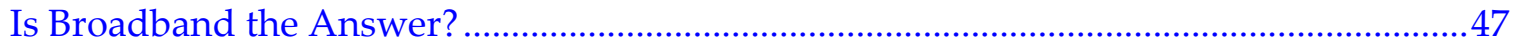

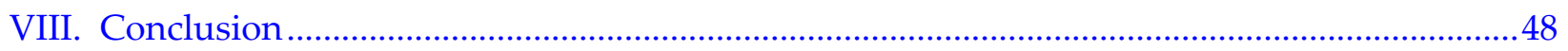

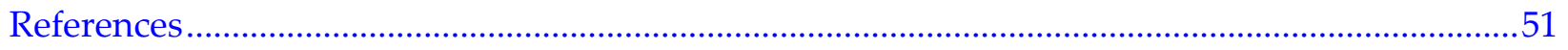

Tables and Figures 


\section{Innovation, Demand, and Supply, Page 1}

\section{Introduction}

No macroeconomic magnitude is more important for the future evolution of the economy than productivity growth, and none is harder to predict. Productivity growth forecasts are needed by monetary policymakers attempting to gauge the growth rate of potential output, the economy's "speed limit." So too is a predicted path of future productivity growth needed for forecasts of future government budgets, deficits, debt, and dates of potential Social Security crises, not to mention the future revenue and employment requirements that guide capital spending plans in every sector of private industry.

Yet, without exception, economists failed to forecast the marked acceleration of U. S. productivity growth after 1995, just as they had failed to anticipate in advance the two-decade slowdown in productivity growth after 1972. With both of these major failures as precedents, it is surprising that there is such a widespread consensus that the post-1995 productivity revival will continue into the indefinite future - that is, that the productivity growth recorded from 1995 to 2002 is more relevant to the long-term future over the next decade or two than the more dismal precedent of 1972 to 1995 . The very phrase "New Economy" connotes such a permanent change in regime, in contrast to a hypothetical alternative label, such as "bubble economy," that would treat the change in regime as temporary and short lived. Is such an assumption of permanence in the productivity growth revival warranted? Did the revival contain one-time elements that are unlikely to be repeated?

\section{Productivity Growth and ICT Investment}

Important studies of the post-1995 productivity growth revival have concluded that its 


\section{Innovation, Demand, and Supply, Page 2}

primary source, and perhaps its only source, was the post-1995 acceleration of growth in real investment in information and communication technology (ICT). This paper begins by examining the record of U. S. productivity growth, distinguishes between cyclical and structural elements of the post-1995 revival, and then reviews evidence on the role of ICT investment in achieving the revival. The major conclusion is that the magnitude of ICT investment's contribution to the productivity growth revival has been exaggerated; ICT deserves substantial credit, but not all the credit that it has previously received. In reaching this conclusion, we focus primarily on the example of the retail trade sector, which emerges both as a primary location of the revival in the United States and as by far the most important industry explaining why the United States enjoyed a revival while Europe did not.

Whether ICT investment explained half, most, or all of the US productivity growth revival, clearly a critical ingredient in predicting future productivity growth is to determine whether ICT investment will soon return to the heady growth rates of the late 1990s, or whether instead that growth rested on unsustainable elements that are unlikely to be repeated. The core of the paper is suggested by its subtitle, "Does Supply Create its Own Demand?" When steady advances in chip-making technology create geometric increases in the supply of computer power, does the marketplace automatically generate a demand for all that new computer power? This paper argues that supply does not automatically create its own demand, and that a continuing explosion of computer power over the next decade may lead to a steady decline in the share of nominal GDP devoted to current-dollar spending on ICT investment, rather than a return to the high growth rates of real ICT investment experienced in the 1990s. "The real problem is demand. It seems that the supercharged spending on technology between 1998 and 2000 owed 
Innovation, Demand, and Supply, Page 3

much to the coincidence of business, product, and liquidity cycles. There is an underlying noncyclical growth story, but it is smaller than we thought” (Lex, 2001).

\section{Macro: The Positive Feedback Loop}

The treatment of supply and demand for ICT investment is divided into two parts, which, in shorthand, can be considered the "macro" component and the "micro" component. The macroeconomic environment of the late 1990s reflected a remarkable "positive feedback loop" in which four major factors each achieved historically unprecedented performance, and in doing so, fed back and reinforced the behavior of the others. The boom in ICT investment, created by a confluence of microeconomic supply and demand elements described separately, fueled the stock market boom and contributed to low inflation. The stock market provided cheap finance to spur the ICT investment boom and added to output growth through its wealth effect on consumer behavior. Low inflation made it possible for the Federal Reserve (the Fed) to avoid tight monetary policy, while monetary policy, by keeping interest rates relatively low, boosted the demand for ICT investment and supported the stock market boom. Each of these elements made the demand for ICT investment higher than it would have been otherwise, and created a larger response of real ICT investment to rapid declines in ICT prices than would have occurred without the macro positive feedback loop.

\section{Micro: The Unsustainable Demand for ICT Equipment in the Late 1990s}

An acceleration in the rate of decline of computer prices, made possible by a faster "Moore's Law" cycle in the development of new computer chips, kicked off the New Economy ICT boom of the late 1990s. Prices that fell more rapidly encouraged firms and consumers to 


\section{Innovation, Demand, and Supply, Page 4}

replace old computers more quickly. Yet the demand for these ever-cheaper computers depended in part on the development of new reasons to buy them, and several factors, most notably the invention of the World Wide Web (WWW), spurred an explosion in demand that matched the expansion of supply. The ongoing evolution of technological development in the supply of computer power may not, however, generate a repeat occurrence of the demand for ICT investment equipment experienced in the late 1990s. Our analysis begins with the overhang of underutilized fiber-optic cable and telecom equipment, perhaps the greatest technological bubble in the history of the modern world. We continue with the surfeit of equipment no longer needed by failed e-commerce firms, the "dotcoms," the dimming prospect that the Internet will live up to its initial promise for either consumer e-commerce or business-to-business commerce, and our most important and controversial proposition that software innovation has failed to take advantage of explosive growth in hardware capacity, leaving both business firms and consumers lacking reasons to replace their old computers at anything like the pace that was common in the 1990s. The section on the micro demand for computer power can be summarized as saying "there can be many slips between the cup of semiconductor technology and the lip of macroeconomic performance."

The paper begins with the bare facts about the productivity revival, the distinction between cyclical and structural components of the post-1995 revival, and the contribution of ICT investment to the revival. We then argue that previous studies may have overstated the importance of ICT investment in the revival and link this overstatement to the puzzling failure of Europe to achieve a productivity growth revival of its own. Whether the ICT investment boom was the sole cause of the productivity growth revival or only a large cause, its role in the revival 
Innovation, Demand, and Supply, Page 5

was central, raising the question whether it can recur in the future or was fundamentally a temporary phenomenon. The middle section of the paper is devoted to the macro elements, the "positive feedback loop" that fed the economy's strength and created a greater response of demand for ICT equipment than would have occurred otherwise. The final section of the paper is devoted to the micro elements of unsustainability in the late 1990s ICT investment boom.

\section{Dimensions of the Post-1995 Productivity Growth Revival}

This section describes the basic dimensions of US productivity behavior over the postwar period and in greater detail for the 1990s. We then turn to an analysis of the cyclical component of the late 1990s' productivity growth revival and to an interpretation of the more recent upsurge of productivity growth experienced in late 2001 and early 2002 .

\section{The Record of Productivity Growth since 1950}

Table 1 presents the basic dimensions of the post-1995 US productivity growth revival in contrast to the previous postwar period. The analysis is based on quarterly data for four sectors published by the US Bureau of Labor Statistics (BLS): nonfarm private business, manufacturing, and two subdivisions within manufacturing: durables and nondurables. In addition, data for nonfarm nonmanufacturing, although unpublished, can be calculated as a residual. ${ }^{1}$ The left three columns of Table 1 exhibit annual growth rates of output per hour in each sector for the longer intervals divided in 1972:Q2 and 1995:Q4. The right three columns

1. This calculation is performed using 1996 weights of nominal (current-dollar) spending in each sector. The nonfarm private business sector is about 78 percent of GDP, the manufacturing sector is 16 percent, and the nonfarm nonmanufacturing "residual" sector is about 62 percent of GDP. 


\section{Innovation, Demand, and Supply, Page 6}

divide the most recent 1995-2002 interval into three subintervals divided in 2000:Q2 and 2001:Q3, quarters chosen to encompass the period of slow growth in real GDP.

Looking first at the broadest aggregate, the nonfarm private business sector in the top line, we see that the annual rate of productivity growth accelerated by 1.11 percentage points after 1995, and the rate achieved after 1995 of 2.53 percent almost matched the 2.66 rate of the earlier postwar era, 1950-1972. The post-1995 revival for nondurable manufacturing was similar, with a pickup of 0.90 percent and a post-1995 growth rate almost as fast as in 19501972. The pattern for durable manufacturing is different, with no slowdown at all, but rather an initial acceleration after 1972 and an even greater second-stage acceleration after 1995. The residual nonfarm nonmanufacturing sector (most of the economy) did worse in 1995-2002 relative to pre-1972 than did the entire economy, simply because durable manufacturing did so much better. The post-1995 acceleration was 1.05 percent, but the post-1995 growth rate of 2.05 fell well short of the pre-1972 growth rate of 2.64 percent. A puzzle that has perplexed many observers, including Griliches (1994), is that, in the earlier postwar era, productivity growth proceeded at roughly equal rates in manufacturing and the rest of the economy (ie, the residual sector), and this is validated in Table 1, but the 1972-1995 slowdown period was entirely concentrated in nonmanufacturing with no slowdown at all in manufacturing. The post-1995 period witnessed a substantial recovery in nonmanufacturing, but not enough to close the gap with the manufacturing sector.

The right half of Table 1 decomposes the post-1995 period into the boom period of the late 1990s ending in 2000:Q2, the period of slow output growth over the following five quarters, followed by the recovery period after 2001:Q3. Productivity growth responded to the output 


\section{Innovation, Demand, and Supply, Page 7}

growth slowdown by decelerating sharply during the five quarters of slow output growth, and in the durable manufacturing sector productivity growth was essentially zero during this interval. Then, when the economy recovered after 2001:Q3, productivity growth exploded to rates even faster than in 1995-2000 in each sector.

\section{Cyclical Dimensions of Productivity Growth}

Ever since the early work of Hultgren (1960) and Okun (1962), economists have recognized and attempted to quantify the procyclical component of productivity growth. But the nature of this behavior is not widely understood, and it does not correspond to the official dates at which expansions end and recessions begin. As examined by Gordon (1993), productivity growth is cyclical because the change in hours of labor input lags behind changes in output, so that an acceleration or deceleration of output growth causes a short-run acceleration or deceleration of productivity growth. In addition, the elasticity of hours growth to output growth (relative to the trends in both hours and output) is less than unity, implying that productivity grows faster than its trend whenever output grows faster than its trend.

Several methods are available to separate the cyclical component of productivity from its underlying trend. The most straightforward method to estimate the trend in any time-series variable is the Hodrick-Prescott (1981) filter. ${ }^{2}$ Figure 1 displays two different growth rates of output per hour for the aggregate US economy (the nonfarm private business sector). The solid black line is simply a four-quarter moving average of aggregate productivity growth, while the

2. Gordon's (1993) technique was to conduct a grid search for the productivity trend that provides the best fit in an econometric equation relating changes in hours to lagged changes in hours and current and lagged changes in output. Results using this technique on recent data yield conclusions similar to the Hodrick-Prescott results discussed in the text and displayed in Figure 1 and Table 2. 


\section{Innovation, Demand, and Supply, Page 8}

line of small black diamonds is the Hodrick-Prescott trend. ${ }^{3}$ The trend displays a more subtle version of postwar productivity growth history than the simple "fast-slow-fast" version of Table 1. Trend growth peaked in the early 1960 s, slowed down steadily until about 1980, and then revived in stages through the late 1990s. Also visible in Figure 1 is an excess of actual overtrend productivity growth in the late 1990s, a shortfall below trend growth in 2001, and then a resurgence to above-trend growth in early 2002.

Table 2 summarizes the information in Figure 1 for decades prior to 1995 and three intervals since 1995. Prior to 1995 each decade exhibits small cyclical effects, alternating across decades. It is interesting that a period as long as a decade is not enough to extinguish the cyclical effect; this depends on economic conditions in the initial and terminal years chosen for each decade. Since 1995 there was a positive cyclical effect during 1995-2000, then a negative cyclical effect for the five quarters of slow real GDP growth between mid 2000 and 2001:Q3, followed by a very strong cyclical growth resurgence in the final three quarters. The cyclical effect of 0.44 points for the 1995-2000 period is consistent with my previous writing, which argued that a significant fraction, perhaps one third, of the post-1995 productivity growth revival through mid-2000 could be interpreted as cyclical rather than structural. ${ }^{4}$

This leaves the final upsurge of productivity growth in late 2001 and early 2002 open to interpretation. Most commentators have interpreted this episode as indicating that trend growth

3. Users of the Hodrick-Prescott method must specify a "smoothing parameter." Most users choose the same parameter (1600) used in the original Hodrick-Prescott research, but this yields too variable a trend that, for instance, exhibits a substantial decline in trend output during the Great Depression of the 1930s. The trend displayed in Figure 1 uses a parameter of 6400 that imposes slightly more smoothness.

4. Based on data through 1999:Q4, Gordon (2000, Table 2, p 55) estimated a cyclical effect of 0.50 points, almost identical to that displayed in Table 2 . 
may have accelerated again to 2.50 or even 2.75 at an annual rate. However, their optimism is countered by three historical precedents, as shown in Table 3. Very strong productivity growth was registered in the first four quarters of the economic recoveries that began in early 1975, late 1982, and early 1991, yet in each case the following two years registered dismal productivity growth at or below the trend rate for that period. These precedents make it likely that in 2003-04 productivity growth will settle back at or below its trend value of 2.25 percent per year, displayed in Table 2. Stated another way, the initial quarters of a business recovery typically combine a jump in output growth with the lagged effect of firms to cut costs and reduce employment. Only after the recovery is well underway does hiring begin in earnest.

\section{The Contribution of Hi-tech Investment to the Productivity Growth Revival}

The post-1995 productivity growth revival has generated a growth industry of its own, in the form of academic analyses of the sources of the revival. In this section we examine the latest decomposition of the sources of the revival by one of the leading research teams on this topic and then raise questions about their results.

\section{The Sources of Growth}

The leading studies of the interplay between ICT investment and the productivity growth revival are by Jorgenson and Stiroh (2000), Jorgenson $(2001,2002)$, and Oliner and Sichel $(2000,2001,2002)$. The most recent results of Oliner and Sichel are presented in Table 4. Fortunately, this analysis, which extends through 2001, can be examined in a straightforward way without any need to separate changes in trend from cyclical effects, since the Oliner-Sichel 
Innovation, Demand, and Supply, Page 10

1995-2001 growth rate of 2.25 percent (Table 4, top line, middle column) is almost identical to the trend estimate for the same period in Table 2 above. ${ }^{5}$ Stated another way, when the analysis includes both the positive cyclical effect for 1995-2000 and the negative cyclical effect for 2001, these effects exactly cancel out.

The Oliner-Sichel method is to start with labor productivity growth and then subtract the contribution of capital deepening and changes in labor quality, arriving at the growth rate of multifactor productivity (MFP) as a residual. Then the location of multifactor productivity growth by industry is examined, and the total of MFP growth is disaggregated into the portion occurring in the ICT sector and a residual for other sectors. The findings reported in Table 4 are very striking. As shown in the right column, the total revival of labor productivity growth is 0.85 points, divided into contributions of 0.55 points of ICT capital deepening, 0.43 points of acceleration in MFP growth in the ICT industries, -0.10 contribution of capital deepening for non-ICT capital, and a -0.02 contribution of the acceleration of MFP growth in the non-ICT part of the economy. In short, Oliner and Sichel overexplain the post-1995 productivity growth revival without any reference to innovation or organizational improvements outside of the production and use of ICT capital. Their conclusion coincides to an uncanny degree of precision with that reached more than two years earlier by Gordon (2000). ${ }^{6}$

5. The combined annual growth rates in Table 2 of actual and trend for the period 1995:Q4-2001:Q3 are both 2.17 percent, implying a cyclical effect of 0.00 percent.

6. Gordon (2000, Table 2) calculated a residual acceleration in MFP outside the ICT sector of 0.02 percent per year for the period ending in 1999:Q4, compared with Oliner and Sichel's -0.02 percent per year for the period ending with the full year 2001. While the time periods are different, Gordon's residual deducted a cyclical effect for the period ending in 1999:Q4 that is not necessary to deduct when the time period ends in 2001. 
Innovation, Demand, and Supply, Page 11

\section{Has the Contribution of Hi-tech Investment been Exaggerated?}

The Oliner-Sichel results do not imply that the only "action" in the economy has been located in sectors making computers, servers, peripherals, routers, software, and fiber-optic cable. Their contribution from the use of ICT equipment ( 0.55 points in Table 4$)$ is higher than their contribution from the production of ICT equipment ( 0.43 points). There has clearly been great dynamism in some industrial sectors that make heavy use of computers. Numerous studies, especially Triplett and Bosworth (2002) and Nordhaus (2002b), pinpoint wholesale and retail trade and securities trading as the industries outside of ICT manufacturing where the productivity growth revival is most evident.

Four related and complementary issues lead us to question whether the Oliner-Sichel methodology attributes too much of the post-1995 productivity growth revival to the use of ICT equipment (we have no quibble with their calculations of the contribution of ICT production. First, the Oliner-Sichel technique requires that the full productivity payoff from the use of computers occurs at the exact moment that the computer is produced. ${ }^{7}$ Leaving aside any delay between production and installation, they assume that the computer produces its ultimate productivity benefit on the first day of use. Numerous observers, led by David (1990), argue instead that there is a substantial time delay necessary for firms to make the organizational changes needed to take advantage of new hardware and software. If there is a substantial delay in the real world that is not taken into account by the Oliner-Sichel method, then they exaggerate the contribution of ICT capital-deepening to the post-1995 revival. A corollary is that, in years

7. Recall that the GDP statistics on which they rely measure output by production and treat any unsold goods as inventory accumulation, a part of GDP. 


\section{Innovation, Demand, and Supply, Page 12}

such as 2001 and 2002 when ICT investment has declined, there are substantial leftover benefits from the previous ICT boom of the late 1990s that may support productivity growth even if ICT investment remains in a slump.

A second qualification relates to the robust productivity revival recorded in the retail sector, noted by Triplett-Bosworth (2002), Nordhaus (2002b), and others. This was concentrated in "large stores offering a wide array of goods accompanied by low prices and relatively high use of self-service systems" (Sieling, Friedman, and Dumas 2001, p 10). A complementary finding by Foster et al. (2002) based on a study of individual retail establishments shows that all of the retail productivity growth (not just the revival but the entire measured amount of productivity growth in the 1990s) can be attributed to more productive entering establishments that displaced less productive existing establishments. The average establishment that continued in business exhibited zero productivity growth, and this despite the massive investment of the retail industry in ICT equipment such as bar-code scanners that presumably went to both old and new establishments. In the Foster results, productivity growth reflects the greater efficiency of newly opened stores, and the Sieling comment implies that most of these highly efficient new stores are large discount operations, the proverbial "big boxes" such as Wal-Mart, Home Depot, Best Buy, Circuit City, and new large supermarkets.

But the Sieling and Foster findings seem to conflict with the Oliner-Sichel implication that all of the productivity revival in retailing was achieved by purchasing new computers, software, and communications equipment. All retailers, whether new establishments of the 1990s or older establishments of the 1980s or prior decades, have adopted ICT technology. Bar- 


\section{Innovation, Demand, and Supply, Page 13}

code readers have become universal in new and old stores. The check-out process at Home Depot involves laser bar-code readers that operate identically to the bar-code readers in the ancient hardware store that I patronize in my home town of Evanston, Illinois, for example. ${ }^{8}$ It is likely that the productivity revival in retailing associated with newly built "big box" stores involves far more than the use of computers, including large size, economies of scale, efficient design to allow large-volume unloading from delivery trucks, stacking of merchandise on tall racks with fork-lift trucks, and large-scale purchases taken by customers in shopping carts to vehicles in adjacent open parking lots.

In the taxonomy of Table 4, these sources of efficiency gains should count as a contribution of non-ICT capital (ie, big-box structures and fork-lift trucks) and organizational improvements that raise MFP in the non-ICT sector. The possibility that Oliner-Sichel exaggerate the role of ICT capital deepening, or indeed of ICT gains in MFP, would imply that the residual role of non-ICT MFP growth is greater than it appears from Table 4. One may speculate that computers in reality earned less than the competitive rate of return assumed by Oliner-Sichel, and that non-ICT capital earned more than a competitive rate of return. This or some other related discrepancy between reality and the Oliner-Sichel framework would be necessary to reconcile their results with those of Foster, and this possibility may extend beyond retailing to the wholesale trade and securities trading sectors, where impressive productivity gains have also been recorded.

The third reason to doubt the Oliner-Sichel decomposition is provided in a recent paper

8. Virtually the only remaining traditional hardware store in Evanston, Lemoi Hardware advertises that it is "Evanston's oldest store, established in 1896." Fortunately, it is heavily patronized, stocked to the rafters with every conceivable type of merchandise, and is currently expanding its floor space by 60 percent. 
Innovation, Demand, and Supply, Page 14

by Daveri and Mascotto, who develop data on productivity growth by U. S. states. They agree with Oliner-Sichel that the production of IT equipment was a central component of the late 1990s productivity growth revival but they find no evidence that the use of IT equipment made a

contribution. More specifically, they find that the productivity growth revival mostly occurred in those states that are "intensive in the production of IT goods and services as well as of non-IT durable goods. When those states are excluded from the sample, the remaining states do not exhibit any significant acceleration in producdtivity. In particular, the association between productivity and gains and IT use is at best weak at the state level" (Daveri-Mascotto, 2002). This finding is complementary to our conclusion reached above that the productivity revival in retailing involved factors other than the use of IT, and brings us to the fourth and final reason to doubt the Oliner-Sichel results, namely the divergent productivity growth experiences of the United States and Europe.

\section{The Puzzling Contrast between the United States and Europe}

If the decomposition of growth sources is a booming academic industry on the west side of the Atlantic, laments about Europe's performance are the corresponding concern of academics on the east side of the Atlantic. Although the United States enjoyed a productivity growth revival after 1995, a growth deceleration occurred in numerous European countries as well as in the European Union as a whole. How could ICT be the main source of the US growth revival, as described in the work of Oliner-Sichel summarized in Table 4 above, while Europe fell behind? Business firms, not to mention university professors, use the same PCs and Microsoft software 


\section{Innovation, Demand, and Supply, Page 15}

everywhere in Europe, bar-code scanners are widely used in European retailing, and most European countries are ahead of the U. S. in the penetration of mobile telephones.

Part of the European puzzle is resolved when we recognize that heterogeneity among European countries is more pronounced than the difference between the European Union and the United States. Numerous studies have shown a relatively strong positive correlation between MFP growth and measures of ICT intensity, for example, the ratio of ICT expenditure to GDP or the change in PC intensity per 100 inhabitants over the 1990s. In such comparisons, numerous countries achieve higher MFP growth rates than the United States over the 1990s-these countries include Ireland, Finland, Sweden, Denmark, Norway, Canada, and Australia. Some, but not all, of these countries surpass the United States in PC intensity and/or in the share of ICT expenditure. What differs most between Europe and the United States is the low level of PC adoption and ICT expenditure in the "olive belt" ranging from Portugal and Spain in the west to Italy and Greece in the east. ${ }^{9}$ The contrast between the Nordic and olive-belt countries suggests irreverent comments about how Scandinavians in their dark winters find PCs more appealing than do olive-belt residents cavorting on their sunny beaches.

Contrasts within Europe also suggest that perhaps we could try to disaggregate the United States to provide a more appropriate comparison with Europe. Silicon Valley could be compared with Ireland and Finland; New England could be compared with Denmark and Sweden; Texas with Australia, and the midwestern heartland with France and Germany. What stands out in this suggestion is the absence of any US equivalent for the European olive-belt countries. Political

9. Scatter plots supporting these correlations between MFP growth and computer intensity are presented in Bartelsman et al. (2002, Figures 8 and 9). 


\section{Innovation, Demand, and Supply, Page 16}

borders are a product of history, and perhaps the United States would look more like Europe, which includes the olive belt, if we were to aggregate US data with those for the "tequila belt" (Mexico).

Quantitative evidence that provides our third reason to doubt the Oliner-Sichel results is provided by van Ark et. al. (2002). As shown in Table 5, van Ark supports the widespread impression that America accelerated while Europe fell behind. The top line in Table 5 shows that US productivity growth accelerated by 1.1 percent in the late 1990s while European growth decelerated by 0.9 percent, a mirror-image performance. An initial caveat is that Europe looks much better when the two halves of the 1990s are aggregated into a single 1990-2000 period; European productivity growth for 1990-2000 averages out to 1.95 percent per year, considerably higher than US growth of 1.65 percent per year. Note that these numbers for the U. S. differ from previous tables by covering the entire economy (GDP) rather than the nonfarm private business sector.

The van Ark study allows us to trace the location of productivity growth accelerations and decelerations to particular industrial sectors, divided into ICT-producing, ICT-using, and non-ICT industries. As we have already seen in Table 4, there has been no productivity revival in US industries that are classified as neither ICT-producing nor ICT-using, and this is confirmed on the bottom line of Table 5 for the United States. These industries are also the core of the European problem, exhibiting a deceleration in the late 1990s greater than the deceleration of the European economy as a whole. Surprisingly, ICT-producing industries exhibited both higher productivity growth and a greater acceleration in the late 1990s in Europe than in the United States. The core of the US success story appears to have been in ICT-using industries - that is, 


\section{Innovation, Demand, and Supply, Page 17}

the same retail, wholesale, and securities trading industries already discussed. A separate analysis by van Ark et al. (2002, Figure 2a) shows that literally all of the productivity growth differential of the United States over Europe in the late 1990s came from these three industries, with retail contributing about 55 percent of the differential, wholesale 24 percent, and securities trading 20 percent. The remaining industries had small positive or negative differentials, netting out to zero. As might have been expected, the United States-Europe differential was negative in telecom services, reflecting US backwardness in mobile phones.

These results for Europe bring together our discussion of retailing in the previous section and here as a major factor explaining Europe's poor performance in the late 1990s. Just as we argued earlier that the US retailing sector has achieved efficiency gains for reasons not directly related to computers, including physical investments in a new type of "big box" organization, so we can suggest in parallel that Europe has fallen back because European firms are much less free to develop the "big box" retail formats. ${ }^{10}$ Impediments include land use regulations that prevent the carving out of new "greenfield" sites for "big box" stores in suburban and exurban locations, shop-closing regulations that restrict the revenue potential of new investments, congestion in central-city locations that are near the nodes of Europe's extensive urban public transit systems, and restrictive labor rules that limit flexibility in organizing the workplace and make it expensive to hire and fire workers with the near-total freedom to which US firms are accustomed.

When confronted with this evidence, Europeans raise a broad set of issues that extend beyond the scope of this paper. Far from praising American land-use planning (or lack of

10. Any generalizations here about "Europe" must be qualified by differences across countries. The Germans until recently were notorious for restrictive shop-closing hours, while the French firm Carrefour and the Swedish firm Ikea are innovators in "big box" retailing formats. 


\section{Innovation, Demand, and Supply, Page 18}

planning) that facilitates the growth of suburban "big box" stores, they praise their own densely populated central cities with their proliferation of small individually owned shops. Some defend small-scale European retail formats by praising an alleged European "taste for variety" that differs from their image of the United States as a homogenous country in which everyone eats Wonder Bread. Americans would respond that chains like Whole Foods routinely sell at least 60 different types of bread every day, and that the variety of light bulbs, tools, and fastening devices in a typical American Home Depot would dazzle any European looking for variety. While admiring the pedestrian walkways of European cities from Stockholm to Frankfurt to Lisbon, one is faced with a difficult tradeoff between urban amenities and raw productivity, that is, retail real value added per hour.

In conclusion we have found four separate reasons to suspect that the Oliner-Sichel methodology overstates the role of IT investment as a source of the post-1995 productivity growth revival: (1) the likely delay in the impact in the productivity payoff of IT investment, in contrast to the instantaneous payoff assumed by Oliner-Sichel; (2) the micro evidence on U. S. retailing that shows a productivity revival only in new establishments and no productivity growth in older establishments, despite their extensive use of computer technology; (3) the cross-state evidence showing no productivity revival in states that are intensive in computer use; and (4) the gap between the growth rate of retailing productivity in the U. S. and Europe despite the use of computer technology on both sides of the Atlantic. Overall, we conclude that ICT investment has been exaggerated as the sole source of the US productivity revival of the late 1990s, and it is even clearer that lack of ICT investment has been wrongly cited as the main source of the contrasting productivity performance in Europe. Since the Oliner-Sichel procedure obtains a 
Innovation, Demand, and Supply, Page 19

large contribution of computer use by assuming that computer capital has the same rate of return as other capital, their apparent exaggeration of the impact of computer use on productivity growth may imply indirectly that computer investment in the late 1990s had a sub-par rate of return, and in fact we know that the hardware and software purchased and developed by failed dotcoms had a negative rate of return.

\section{Positive Feedback Loops among the ICT Investment Boom, the Stock Market, Low Inflation, and Monetary Policy}

We have now examined the extent to which the post-1995 productivity growth revival may have contained a cyclical component, how much of it can be attributed to the boom in ICT investment, whether standard estimates of ICT's contribution may have been exaggerated, and why Europe did not experience a productivity growth revival. Whether the ICT investment boom was the sole cause of the US productivity growth revival or only a very large cause, there is no doubt that the ICT investment boom deserves substantial credit for the productivity growth revival. Accordingly, the future growth of productivity will depend at least in part on whether ICT investment soon returns to growth rates typical of the late 1990s or settles down to much slower growth rates, perhaps even slower than in the $1987-1995$ period.

We now turn to the core of this paper, which is to identify unsustainable sources of the ICT investment boom of the late 1990s. All of these sources fall under the general heading suggested by the paper's subtitle, “Does Supply Create its own Demand?" We treat the geometric increase in computer power as a given, and attempt to identify the sources of the robust demand for computer power in the late 1990s that might not recur in the future. These fall into two general categories: macroeconomic and microeconomic. The macro sources of demand 
Innovation, Demand, and Supply, Page 20

are described as a multidimensional feedback loop in which the ICT investment boom interacted positively with the stock market, inflation behavior, and monetary policy. The micro sources of demand are traced to particular events in the evolution of telephone equipment, computer hardware, and software technology.

\section{The Hi-tech Investment Boom}

The late 1990s were notable both for an amazing acceleration in the growth of real computer investment and for a simultaneous acceleration in the rate of price decline of computer power. In fact, one hypothesis is that the investment boom simply reflected the faster rate of price decline. The dimensions of this phenomenon are illustrated in Figure 2. Plotted on the same scale are four-quarter growth rates of real investment in computers and peripherals and the change in the deflator for the same category of equipment. The upper (solid) line is the real investment series, with growth rates accelerating from 19 percent per year during 1987-1995 to 33 percent per year between mid 1995 and mid 2000. During the two years following mid 2000, the growth rate decelerated sharply to 4.6 percent per annum, well below the average of $1987-$ 1995.

The lower (dashed) line is the growth rate of the computer deflator, with a rate of change accelerating from around -15 percent per year before 1995 to between -30 and -35 percent per year during 1995-1999, followed by a return closer to the pre-1995 growth rates. Was the investment boom simply the counterpart of the accelerated rate of price decline? If the boom reflected only substitution with a price elasticity of unity, then nominal spending on computers would not have increased.. As shown in Figure 3, the investment boom went beyond that. Computer investment as a share of nominal GDP was not constant in the late 1990s, but rather 


\section{Innovation, Demand, and Supply, Page 21}

jumped after 1995 from about 0.75 percent to close to 1.0 percent before falling back to 0.7 percent in 2001-2002. The drop in the nominal computer share in 2001-2002 reminds us that a rapid rate of price decline for high-tech equipment is not enough to guarantee a continuous investment boom; if the demand is not there, then the nominal share can decline as prices continue to fall relative to prices in the rest of the economy.

The phrase New Economy became widely adopted to describe the US macroeconomic miracle of the late 1990s, and definitions of the New Economy centered not just on the productivity growth revival but also on the burst of growth in high-tech investment visible in Figure 2. In fact it became common in the late 1990s for some commentators (see Gordon 2000) to treat the accelerated rate of price decline of computers as the defining characteristic of the New Economy. However, this emphasis on the rate of price decline implicitly treats the acceleration of technological change in high-tech equipment as both necessary and sufficient to generate an investment boom and a productivity revival. As we shall see, a technological acceleration in supply does not guarantee that the demand for all that equipment will emerge, and in this sense any definition of the New Economy has to include innovation both in computer technology and in new uses for computers.

Thus far we have emphasized the computer part of ICT investment to the exclusion of software and telecom investment, mainly because the price deflators for computers are much better than those for software and telecom (where the rate of price decline is generally assumed to be understated). ${ }^{11}$ However, deflators do not matter for nominal shares, and we see in Figure 4 that the nominal share of all ICT investment (computers, peripherals, software, and telecom)

11. On the issue of software and telecom deflators, see Jorgenson and Stiroh (2000, pp 153-160). 
Innovation, Demand, and Supply, Page 22

experienced more robust growth than for computers alone in the 1990s. While the computer share in Figure 3 fell back in 2001-2002 to its level of 1984, the share of all ICT investment in 2001-2002 was a full percentage point higher than in the mid-1980s, although more than half a point below its peak of 1999-2000. Why did the prior upsurge in the ICT investment share in the 1980s not create a productivity revival like that of the late 1990s? This is one of several circumstantial pieces of evidence implying that the role of ICT investment in the late 1990s productivity revival, as argued above, may have been exaggerated in analyses like that of Oliner and Sichel as summarized in Table 4.

\section{Pillar of the Positive-feedback Loop: the Stock Market}

Whatever the rate of price decline in computer equipment, as displayed in the bottom frame of Figure 2, the growth rate of real investment depended crucially on the sources of demand for computers and other types of ICT investment. This growth rate was increased by the stock market boom, both directly through the role of stock market finance in helping old and new firms alike buy massive amounts of ICT equipment, and also through the role of the stock market in propelling overall economic growth through the wealth effect on consumption expenditures.

The S\&P 500 stock market average exactly tripled from May 1995 to March 2000 and then fell by almost half by October 2002. ${ }^{12}$ This reflected in large part the marked increase in corporate profits at roughly the same time. The most widely watched measure of profits refers to the reported profits of the S\&P 500 companies, an amount that roughly quadrupled from about $\$ 125$ billion in 1991 to about $\$ 500$ billion in mid-2000 before collapsing to around $\$ 200$ billion

12. The monthly average of the S\&P 500 index for May 1995 was 508, and the peak reached on March 24, 2000, was 1527. The value reached on October 7, 2002, was 785, fully 49 percent below the peak. 
Innovation, Demand, and Supply, Page 23

in late 2001. If the $\mathrm{S} \& \mathrm{P}$ measure of reported profits were the only available measure, there would be no mystery surrounding either the stock market boom or its collapse, since the S\&P index increased and then decreased by roughly the same percentage as profits. However, as pointed out by Nordhaus (2002a), several other profit measures show different timing, particularly the national accounts (NIPA) measure that peaks much earlier, in 1997 rather than in 2000, and which decreases much less than the S\&P series from 2000 to late $2001 .{ }^{13}$ If market investors had been watching NIPA profits rather than S\&P profits, the stock market might not have increased as much in 1997-2000 nor declined nearly as much after 2000. Nordhaus speculates that the much later peak in S\&P profits may have reflected creative accounting schemes of the type that have created the recent crisis in US corporate governance involving Enron, WorldCom, Global Crossing, Tyco, and others.

If the S\&P 500 stock market index simply echoed reported S\&P earnings, however misleading or inaccurate these may have been, then the stock market boom of the late 1990s was not a "bubble," since it was based on a fundamental factor, namely the perceived value of S\&P earnings. Although the price-earnings ratio for the S\&P 500 did increase substantially between 1995 and 2000, most of this can be explained by a decline in the real interest rate on bonds.

Nordhaus (2002a, Figure 8) shows that the spread between the return on equities (the inverse of the price-earnings ratio) and the real interest rate on government bonds was only slightly lower

13. Nordhaus (2002a, Figure 5) displays four different measures of profits. There are two S\&P indexes, both including and excluding accounting changes, discontinued operations, extraordinary items, and special items. The measure discussed in the text is reported S\&P profits, which includes all these items. There are also two NIPA indexes, including and excluding an inventory valuation adjustment and capital consumption allowances, and the measure discussed in the text includes such adjustments. Major differences in the NIPA indexes compared with the S\&P include their greater comprehensiveness in applying to the entire economy, exclusion of capital gains, basis on economic rather than accounting profits, and treating of stock options as an expense. 
Innovation, Demand, and Supply, Page 24

in 2000 than it was in 1992 or in 1985-1987.

In contemplating the future of the stock market, and hence one of the critical components of the positive-feedback mechanism of the late 1990s, we must assess the future of all three components of the Nordhaus spread: the profits, the price-earnings ratio, and the real interest rate on government bonds. During the prosperous 1960-1973 period, the spread was in the range of 3 to 4 percent, followed by the depressed and inflationary 1973-1983 period with spreads ranging from 5 to 14 percent. In contrast, the spread after 1984, except for a short period in 1989, was in the narrow range of -1 to 2 percent. In fact, the collapse in stock prices through October 2002, together with the decline in bond yields, brought the spread back up to at least 4 , as high as at any time since 1984. At that point the market had itself corrected the widespread perception of irrational exuberance.

Could the spread go back to the range of 0 to 2 percent that has characterized most of the post-1984 period? Another way to pose this question is to ask whether the 1963-1973, 19731983, or post-1984 periods are more relevant to post-2002 stock market spreads and hence prices. An important change that can be dated to $1983-1984$ is a decline in macroeconomic volatility, as measured by various volatility measures of real GDP growth (Blanchard and Simon 2001); this would be expected to decrease the spread between stock and bond yields. Another factor working in the same direction has been the shift from defined benefit to defined contribution pension plans, leading many workers to make regular monthly investments in equities independent of the current state of the stock market.

The previous discussion suggests that the spread could well decline from its value of mid- 
Innovation, Demand, and Supply, Page 25

October 2002 of about 4 percent back toward the 0 -to- 2 percent range that has been the norm since 1984. Interest rates on bonds in late 2002 are abnormally low and could plausibly increase by more than any hypothetical future increase in inflation (discussed below). As Nordhaus shows, S\&P reported profits have been abnormally low in 2001-2002 as the dirty linen of creative accounting has been cleansed. Future S\&P profits may bounce back substantially as this one-time element disappears, even if economic profits do not change appreciably as a share of GDP. ${ }^{14}$ This discussion on causes of the stock market boom of the late 1990s concludes that the bubble element of prices has been squeezed out and that substantial stock market returns for the period after October, 2002, are quite likely.

The effects of the late 1990s stock market boom are easier to describe than its causes. Easy stock market finance fueled start-up companies and the expansion of existing high-tech companies. New companies with only vague business plans and remote prospects for profit were flooded with funds from aggressive venture capital firms and then proceeded to initial public offerings (IPOs) that have since become notorious for providing privileged insiders and friends of brokerage houses with opportunities for guaranteed first-day gains at the expense of ordinary investors. The heady optimism as market participants anticipated unending gains ("Dow 36,000 ”) doubtless led to more finance being shoveled into ICT investment than would otherwise have occurred; the abuses since discovered, as well as the collapse in high-tech stocks, make it unlikely that this supporting component of the ICT investment boom will recur in the foreseeable

14. Nordhaus (2002a, Figure 6) shows that reported S\&P profits were not unusually high as a percent of GDP at the 2000 peak and indeed were lower at that peak than in virtually every year between 1960 and 1980 . This suggests that a substantial rebound in S\&P profits relative to GDP from the 2001-2002 lows is quite likely. 
Innovation, Demand, and Supply, Page 26

future, if ever in our lifetimes. ${ }^{15}$

The ICT investment boom was propelled not just by the stock market but also by the prosperity of the overall economy, feeding back to investment as part of the standard "accelerator" effect. One impetus to economy-wide growth was a two-step feedback from the stock market to ICT investment, working through the wealth effect of the stock market on consumption expenditures. This connection is most vividly illustrated by Figure 5, which compares the household savings rate (dashed line, right scale) with the ratio of the S\&P 500 stock market index to nominal GDP (solid line, left scale). This S\&P ratio more than doubled in the four years between 1995 and 1999, after declining by two thirds between 1965 and 1982 . The negative correlation between the stock market ratio and the household savings rate is evident in the data and is just what would be expected as a result of the wealth effect embedded in Modigliani's life-cycle hypothesis of consumption behavior. Rapid economic growth in the late 1990s was fueled not just by the ICT investment boom, but also by a consumption binge financed by capital gains that allowed consumption expenditures to grow more rapidly than personal disposable income for four straight years. Another source of positive feedback came from the rest of the world outside of the United States. The stock market boom attracted foreign investment that financed the US current account deficit, and this allowed US consumers to expand their purchases of imports far faster than the rest of the world was willing to buy US exports. The resulting appreciation of the US dollar played its own role in the positive-feedback mechanism, as it was the most important single source of the surprisingly low rate of inflation

15. One is reminded of the famous and chilling remark of the British Foreign Minister Sir Edward Grey on August 3,1914, after the British cabinet had made its fateful decision to go to war: "The lamps are going out all over Europe; we shall not see them lit again in our lifetime." 


\section{Innovation, Demand, and Supply, Page 27}

experienced by the United States in the late 1990s.

\section{Low Inflation Enabled Easy Monetary Policy}

Low inflation in the late 1990s allowed monetary policy to avoid a move toward the restrictive spike in short-term interest rates that had ended previous expansions in 1969, 1981, and 1989. The nature of the inflationary surprise is evident in Figure 6, which plots the unemployment rate on the same scale as the inflation rate for the personal consumption expenditures (PCE) deflator. ${ }^{16}$ The unemployment rate in 1999-2000 fell to 4 percent, the lowest rate since 1966-1970, yet in 1998 and early 1999, inflation not only failed to accelerate but actually decelerated.

Taking a general view of the unemployment-inflation relationship, it appears superficially that the only support for a negative Phillips-curve unemployment-inflation tradeoff is based on the 1960s Vietnam-era experience, with a bit of further support from the economic expansion of 1987-1990. In other periods, especially during 1972-1985 and 1995-1999, the unemployment and inflation rates appear to be positively correlated, with the unemployment rate behaving as a lagging indicator, moving a year or two later than inflation. Although this appearance of a positive tradeoff led some economists—notably Robert E. Lucas, Jr. and Thomas Sargent—in the 1970s to declare the Phillips curve to be "lying in wreckage," at the same time a more general model of inflation determination was developed that combined an influence of demand (ie, a negative short-run relation between inflation and unemployment),

16. The deflator for Personal Consumption Expenditures, part of the National Income and Product Accounts, is preferable to the Consumer Price Index, because it has been revised retrospectively to use a consistent set of measurement methods, whereas the CPI is never revised. 
Innovation, Demand, and Supply, Page 28

supply (in the form of "supply shocks" such as changing real oil prices that created a positive inflation-unemployment relation), slow inertial adjustment, and long-run independence of inflation and the unemployment rate. ${ }^{17}$ During the 1980s and the first half of the 1990s, this more general model was adopted as the mainstream approach to inflation determination by textbook authors and policymakers alike, but in the 1997-99 period it was challenged again by the simultaneous decline in unemployment and deceleration of inflation evident in Figure 6.

At the end of the decade, no consensus had yet emerged to explain the positive correlation of inflation and unemployment in the late 1990s. I have attempted (1998) to use a common framework to explain why the performance of the 1970s was so bad and the performance of the 1990s was so good, pointing to the role of adverse supply shocks in the earlier episode and beneficial supply shocks more recently. The first beneficial shock was the post-1995 productivity growth revival, which directly reduced the growth in unit labor costs, and hence inflation, for any given growth rate of nominal wages. If there was a substantial lag in the response of nominal wage changes to faster productivity growth, then the productivity revival contributed directly to lower inflation.

The second and third beneficial shocks were the familiar "old" supply shocks, the falling real prices of imports and energy. Of these by far the most important was the declining real price of imports that was a counterpart to the appreciation of the dollar over the entire period between 1995 and early 2002. I have estimated (1998) that in early 1998 inflation was being held down by more than 1 percent at an annual rate by the behavior of real import prices. The role of real 17. The
Gordon (1997).

17. The more general approach was developed in Gordon $(1977,1982)$, and its evolution is described in Cor 
Innovation, Demand, and Supply, Page 29

energy prices was short-lived, having its maximum impact in holding down inflation in early 1998. Productivity, import prices, and energy prices were joined by two "new" supply shocks: the accelerating decline in computer prices (see Figure 2 above) and a sharp decline in the prices of medical care services made possible by the managed health care revolution.

The confluence of this set of five beneficial supply shocks was central to the longevity of the boom of the 1990s. Low inflation allowed the Fed to pursue a very different monetary policy than in the late 1980s. Yet none of the beneficial shocks was guaranteed to last forever. Indeed, the first to disappear was the energy price effect, which turned around and accounted for most of the doubling of inflation in the price deflator for personal consumption expenditures (plotted in Figure 6) from 1.1 percent in 1998 to 2.6 percent in 2000. ${ }^{18}$

If low inflation in the late 1990s was mainly caused by the beneficial supply shocks, and low inflation in 2001-2002 was caused by a weakening of demand in product and labor markets, what are the prospects for inflation when the economy recovers? This is relevant to the overall themes of this paper, because if there is a substantial risk that inflation will reignite, the response of monetary policy may look more like the late 1980s than the late 1990s, and any substantial upward movement of interest rates on bonds would throw cold water on housing and car sales, on housing refinance, and on any incipient stock market recovery.

A case can be made that, in addition to energy prices, all four of the remaining supply shocks that shifted in a beneficial direction in the late 1990s may turn in the adverse direction

18. Measures of "core inflation" that exclude food and energy prices exhibited only a negligible acceleration from 1998 to 2000, but these core measures are influenced by the other beneficial shocks discussed in this section - namely the productivity revival, the decline of real import prices, the temporary cessation of medical care inflation, and the accelerated rate of decline of computer prices. 
Innovation, Demand, and Supply, Page 30

and indeed may already have done so. Even if productivity growth remains strong, eventually real wage growth will recognize and absorb the productivity growth revival. Indeed, this had already happened in the late 1990s, as annual growth in real compensation per hour accelerated from a mere 0.7 percent during $1992-1998$ to 2.8 percent during $1998-2000{ }^{19}$ The beneficial role of falling real import prices has already greatly lessened in impact, from an annual rate of decline of -3.3 percent per year in $1992-1998$ to -1.2 percent per year in 1998-2002. A continuing decline in real import prices is unlikely, as the dollar has begun to decline from its peak reached early in the year 2002.

Perhaps the greatest single concern for the future of inflation involves medical care prices. Between 1993 and 1996 medical care inflation exhibited a sharp deceleration from roughly double the economy-wide inflation rate to a number almost equal to the overall inflation rate. Yet recently the inflation rate of the personal consumption deflator for medical care has begun to creep up, from 2.1 percent in 1999 , to 2.9 percent in 2000 , to 3.6 percent in 2001 , relative to an overall inflation rate in 2001 of only 2.0 percent. This may be the tip of the iceberg, however, because health care prices are once again becoming a leading edge of inflation. The growth rate of one index of health insurance premiums decelerated from 18 percent in 1989 to 0.8 percent in 1996 , only to reaccelerate again to 13 percent in $2002 .^{20}$ The final beneficial shock of the late 1990s was the more rapid rate of decline in computer prices, and we have already seen (in Figure 2) that the rate of price decline retreated from -30 percent per year in 1995-1999 to an average rate of about -20 percent in 1999-2002.

19. The growth rate of real compensation per hour subsequently slowed back to 0.7 percent per year between 2000:Q2 and 2002:Q2. 
Innovation, Demand, and Supply, Page 31

The response of the Fed's monetary policy is summarized in Figure 7, which compares quarterly values of the Federal funds rate with the output ratio or "gap" - that is, the ratio of actual to potential real GDP. The gap is a commonly used measure how much actual output differs from potential output, i.e., the amount the economy is capable of producing without generating extra inflation. As shown by the right scale, the output ratio rose above 100 percent both in 1988-1990 and in 1997-2000, but the response of the Fed was quite different. In the episode of the late 1980s, the Fed responded to excess output by quickly tightening policy and creating a spike in the Federal funds rate to 9.25 percent in early 1989 . In the late $1990 \mathrm{~s}$, the output ratio rose above 100 percent for a longer period and to a higher level, but the Fed barely touched the Federal funds rate, which varied only in the range of 4.5 to 6.5 percent during the entire period between early 1995 and late 2000 . The distance between the two lines in Figure 7 during the period 1997-2000 can be interpreted as showing the influence of low inflation on monetary policy, and hence low inflation as an enabler of the continued output boom. Once again, there was a positive feedback system, with relatively low interest rates fostering ICT investment and the productivity revival, and the productivity revival feeding back to make its own contribution toward keeping inflation low.

\section{The Interplay of Supply and Demand in the ICT Investment Boom}

We have now seen that the ICT investment boom of the late 1990s, although initially stimulated by technological advances that pushed the price of computer power downward more rapidly than before, did not occur in isolation. In addition to the pure technological stimulus, 


\section{Innovation, Demand, and Supply, Page 32}

ICT investment was funded by ample finance made possible by the stock market boom and relatively easy monetary policy, and ICT investment responded to the boom in the overall economy, which in turn reflected positive feedback among the productivity revival, the beneficial shocks that held down inflation, and low interest rates. Stated another way, if the initial technological stimulus had not been supported by the positive macro feedback loop, a given rate of decline in computer prices would have been accompanied by less real ICT investment and a lower share of nominal ICT investment in nominal GDP than the actual ratio displayed in Figure 3.

But there is another requirement necessary for a technological advance to result in an investment boom and an increased share of computer spending in nominal GDP. There must be a use, that is, a demand, for all that extra computer power. A unique element of the late 1990s is that technological advances in the manufacture of computers coincided with new stimuli to the demand for computers, including but not limited to the invention of the WWW. This interdependence of supply and demand is missed by commentators, such as Jorgenson, who see a simple chain of causation between information technology as an input and economic performance as an output: “... the foundation for the American growth resurgence is the development and deployment of semiconductors" (Jorgenson 2001, p 1).

\section{Moore's Law and the Explosion of Supply}

The specific technological event that made the growth resurgence possible was an acceleration in technical change in the manufacture of microprocessors, the computer chips that provide a computer's computation capacity. The idea of a product cycle in computer chips is summarized by "Moore's Law," a name later given to a 1969 observation by Gordon E. Moore, 
Innovation, Demand, and Supply, Page 33

one of the two founders of the Intel Corporation, that each new microprocessor chip contained twice as many transistors as the previous generation and was released within 18 to 24 months of its predecessor. This implied a logarithmic growth rate of computing capacity at between 35 and 47 percent per year. Rarely if ever has any scientist been so accurate in forecasting the future development of an innovative process. The actual price of computer memory chips declined by 40.9 percent per year during 1974-1996. The price of logic chips, a narrower category more directly comparable to computer microprocessors, declined during 1985-1996 at 54.1 percent per year, followed by an acceleration to a rate of price decline of more than 90 percent per year. As characterized by Jorgenson (2001), "the semiconductor industry shifted from a three-yearproduct cycle to a greatly accelerated two-year cycle."

The calendar of product cycles and Moore's Law may seem confusing at first, because the pre-1995 schedule in which the number of transistors doubled every 18 months seems to conflict with the idea of a three-year product cycle. This apparent conflict is reconciled by the fact that each new generation of chips produced an increase in computation power by more than a factor of two-it is rather more like a factor of four. ${ }^{21}$ If the shortening of the product cycle from three years to two was an ephemeral phenomenon of the late 1990s, then this is one more reason to expect that an ICT investment boom on the same scale will not recur. In the rest of this paper, we will assume that the faster two-year cycle continues for at least another decade. The issue, then, is whether there is sufficient demand for computation power to absorb an increase in

21. The arithmetic of Moore's Law can be better understood as related to the fact that the natural logarithm of 1.0 is 0 and of 2.0 is 0.7 . Thus a doubling of computation power raises the logarithm by 0.7 , which represents a logarithmic growth rate of 46.7 percent over 18 months or 1.5 years. At that rate, the logarithm of computation power over 3 years increases by 1.4, or by a factor of 4.0 (the antilogarithm or exponent of 1.4). 


\section{Innovation, Demand, and Supply, Page 34}

computer power by a factor of 1,000 from a starting date of $2002 ?^{22}$

\section{Why the Demand for ICT Power Matters}

Whether Moore's Law proceeds with a cycle time of two years or three years, there is no doubt that future progress will provide an unbelievable further explosion of computer power beyond what already existed at the peak of the ICT investment boom in mid 2000. But, as we have seen, a rapid decline in the price of computer power does not guarantee a robust expansion in ICT investment. An annual rate of decline in computer prices of, say, 30 percent per year could be accompanied by an annual rate of growth of real computer investment of +60 percent, +30 percent, 0 , or -30 percent. Growth of real investment in this example of +30 percent would imply no change in nominal computer investment. Any lower growth rate in real investment, whether $0,-30$, or any number between, would imply a sharp decline in the share of ICT investment in nominal GDP, as has already occurred between 2000 and 2002. It is this possibility of a continuing decline in the share of ICT investment in nominal GDP that creates the sharpest divide between the economic environment of the late 1990s and the next few years. The evolution of the price and quantity of computer power can be displayed in a simple theoretical diagram, as in Figure 8. Throughout its history, the economics of the computer has featured a steady downward shift in the supply curve of computer attributes at a rate much faster than the upward shift in the demand for computer services. In fact, the story is often told with a theoretical diagram like the top frame of Figure 8, in which the supply curve slides steadily

22. With a product cycle of two years, computation power quadruples every two years and doubles every 12 months. Any variable that doubles in one year must increase by a factor of 1,024 over one decade. 
Innovation, Demand, and Supply, Page 35

downwards from $S_{1}$ to $S_{2}$ with no shift in the demand curve at all. ${ }^{23}$ Ignoring the possibility of a rightward shift in the demand curve (we return to this possibility below), the second distinguishing feature of the development of the computer industry is the unprecedented speed with which diminishing returns set in; while computer users steadily enjoy an increasing amount of consumer surplus as the price falls, the declining point of intersection of the supply curve with the fixed demand curve implies a rapid decline in the marginal utility or benefit of computer power.

The accelerated rate of price decline in computer attributes has been accompanied since 1995 by the invention of the Internet. ${ }^{24}$ In perhaps the most rapid diffusion of any invention since television in the late 1940s and early 1950s, by the end of the year 2000 the percentage of American households hooked up to the Internet reached 50 percent. Surely the invention of web browsers and the explosive growth of e-commerce should be interpreted as a rightward shift in the demand curve in the top frame of Figure 8 from $D_{1}$ to $D_{2}$. Such a rightward shift in the demand curve would imply an increase in the benefits provided by all computers, both old and new. ${ }^{25}$

Although the invention of the Internet is usually treated as revolutionary, a simple analysis of the supply and demand for computer hardware may suggest a more limited role. We

23. Three examples of this graph applied to computers exhibiting no shift in the demand curve are Brynjolfsson (1996, p 290), Gordon (1990, p 46), and Sichel (1997, p 17). The supply curves in this graph have been drawn as horizontal lines, both to simplify the subsequent discussion and because there is no evidence of a rising marginal cost of producing additional computer speed, memory, and other characteristics at a given level of technology.

24. Here to simplify the presentation we will take the Internet as being synonomous with the World Wide Web and the invention of web browsers, although the use of the Internet for e-mail, at least in the academic and scientific community, dates back at least to the early 1980 s.

25. In terms of elementary economics, there is an increase in the consumer surplus associated with the lower supply curve $\mathrm{S}_{2}$ from the triangle $\mathrm{JP}_{2} \mathrm{~B}$ to the larger triangle $\mathrm{KP}_{2} \mathrm{E}$. 
Innovation, Demand, and Supply, Page 36

have already seen that the rate of decline of prices for computer hardware, including peripherals, accelerated sharply after 1995. This fact is shown in the bottom from of Figure 8, which plots the price and quantity of computer characteristics since 1960. The implicit price deflator for computer hardware, including peripherals, declined from 70,969 in 1961 to 20 in 2002 (with a base $1996=100$ ), for an annual rate of decline of 20.0 percent per annum. There has been a corresponding increase in the quantity of computer attributes, and both the rate of price decline and quantity increase accelerated after 1995.

Although the rate of price change has varied over time, a rapid price decline in 19952000 does not distinguish the New Economy from the 1960-1980 interval dominated by the mainframe computer or the 1980-1985 interval dominated by the transition from mainframe to PC applications prior to the invention of the Internet. ${ }^{26}$ If there had been a discontinuous rightward shift in the demand curve for computer hardware due to the spread of the Internet, we should have observed a noticeable flattening of the slope of the price-quantity relationship in the bottom frame of Figure 8a, as the rate of increase of quantity accelerated relative to the rate of decline in price, but we do not. The rate of change of price and quantity both accelerate after 1995 (as indicated by the greater spacing between annual observations) but the slope does not change appreciably, suggesting that the spread of the Internet is a byproduct of rapid technological change that is faster than in previous decades but not qualitatively different in the relationship between supply and demand than earlier advances in the computer industry.

The data on the price and quantity of computer characteristics have previously been used

26. Existing computer price deflators fail to take account of the radical decline in the price per calculation that occurred in the transition from mainframes to PCs (which have been studied only separately, not together). Gordon (1990, p 239) calculates that the annual rate of price decline between 1972 and 1987 would have been 35 
Innovation, Demand, and Supply, Page 37

to "map out" the demand curve (Brynjolfsson 1996, p 290). In fact, the slope of the pricequantity relationship was appreciably flatter during 1972-1987 than during 1987-1995 or 19952000. If the demand curve has not shifted, the inverse of these slopes is the price elasticity of demand, namely $-2.03,-1.33$, and -1.19 in these three intervals, which can be compared with Brynjolfsson's (1996, p 292) estimated price elasticity of -1.33 over the period 1970-1989 (the implied elasticity in the slump period 2000-2002 was only -0.28). The apparent decline in the price elasticity is consistent with the view that the most important uses of computers were developed prior to 1987 , not in the late 1990s.

\section{Unsustainable Sources of Demand for ICT Investment in the Late 1990s}

Our discussion of unsustainable demand for ICT investment begins with the least controversial component of the argument that supply does not create its own demand. It is uncontroversial because it — the bubble and subsequent meltdown in telecom equipment investment, especially in fiber-optic cable and in the communication infrastructure of the Internet—has already happened. We then turn to computer equipment, peripherals, and software, where optimists like Jorgenson point to the inexorable future explosion of computer power made possible by Moore's Law, and we assemble a growing body of evidence showing that much of the extra computer power is not needed and will not be purchased.

\section{The Telecom Equipment Bubble and Meltdown}

Of all the different components of ICT investment, the most staggering mismatch between supply and demand occurred in fiber-optic telephone lines. During the 1990s, new 
Innovation, Demand, and Supply, Page 38

technology made possible an explosion in the carrying capacity of a given fiber-optic line at a pace that made progress in computer microprocessors look anemic by comparison. Until 1995 it was possible to transmit only one color of data-carrying light through fiber-optic lines, but the development of "dense-wave division multiplexing" split the single beam into a spectrum of colors and multiplied capacity by as much as a factor of 300 . Over a seven-year period, the capacity of telephone lines increased by more than in the previous 100 years; the number of onepage e-mails that could be sent over one fiber-optic strand increased from 25,000 in 1995 to 25 million in 2002. Yet the cost of providing 1,000 times more capacity increased minimally and in some cases declined.

Oversupply was so great that the cost of renting an intercity data line dropped at a rate of 67 percent per year between 2000 and 2002, but despite the stimulus to demand from these lower prices, the growth of demand fell so far behind the growth in supply that, in 2002, fully 97 percent of fiber-optic capacity remained unutilized. The implied 3 percent utilization rate was without precedent in industrial history and led to an unparalleled series of corporate bankruptcies and the evaporation of $\$ 2$ trillion in shareholder wealth and 500,000 industry jobs. ${ }^{27}$

Given the advance in technology, another outcome was possible. If each fiber-optic line had such an increase in its capacity, then supply could have remained matched to demand if fewer lines were built. The underlying assumption that led to overinvestment was heady optimism, the same factor that propelled the NASDAQ stock market bubble. One frequently quoted number, which has been traced to a corporate memo written in 1997, was that Internet traffic was doubling every 100 days, implying an annual growth rate of around 1,100 percent 
Innovation, Demand, and Supply, Page 39

(Dreazen 2002). It never occurred to telecom executives, or the Wall Street analysts promoting their stocks, that such growth rates would imply that within a few years every member of the US population would be spending 24 hours per day connected to the Internet, and that Internet revenues would exceed 100 percent of GDP. In actual fact, the annual growth rate of Internet traffic for 2003 has been estimated to be closer to 50 percent per year than 1,000 percent. ${ }^{28}$

Telecom equipment, even more than the stock market, appears to have been history's classic example of "irrational exuberance" in several meanings of that term, including irrational demand forecasts, stock price increases, and debt incurred, resulting in an unprecedented value of equity wiped out in one after another debt-heavy bankruptcy.

\section{Differences between Computer and Telecom Investment}

At first glance, the telecom equipment investment bubble may seem quite irrelevant for computers, peripherals, and software, the heart of the New Economy that made possible the WWW and the dotcom e-commerce revolution. Nothing like the overbuilding of telecom equipment capacity occurred with computer hardware, and the utilization of the equipment devoted to making computer chips, personal computers, laptops, and peripherals such as monitors and printers was closer to 100 percent than the 3 percent recorded for fiber-optic cable.

Yet a central topic of this paper is not utilization rates, but the extent to which the growth rate of ICT investment in the late 1990s was sustainable. For computers, the annual rate of decline of prices provided an ever-growing supply of computer characteristics - that is, speed

from Berman (2002).

28. If supply quadruples every year while demand grows by 50 percent per year, and if demand and supply are equal in year 1, then by year 5 the ratio of demand to supply is only 2 percent. 
Innovation, Demand, and Supply, Page 40

and memory — and the demand for these characteristics was sufficient to boost temporarily the share of nominal computer investment in nominal GDP, as was displayed in Figure 3. However, the core factors that created the demand for computers in the late 1990s were in part unsustainable, and this implies that similar increases in the supply of computer power over the next decade (2002-2012) may be accompanied by a less than proportionate increase in the quantity of computer power demanded by the marketplace.

\section{The Web could be Invented Only Once}

The period between 1995 and 1999 witnessed the instant deployment and diffusion of the World Wide Web (WWW). Whereas few business firms knew anything about web sites in 1995, by 1998-1999 every business, government agency, university, and other nonprofit organization was compelled to develop its own web site. Constructing a web site required buying one or more servers and hiring numerous software engineers to design the pages, their interaction within the site, and the hyperlinks to external sites. The period 1998-2000 represented the peak of this investment activity, with its required purchases of hardware and software, but this level of frenetic activity could not be sustained forever. ${ }^{29}$ Once each component of the web site "went live," subsequently it would need only to be maintained and incrementally improved. The hardware requirements of such incremental improvements may have been minor, even negligible, while the software investment was far less than had been needed to create the initial site.

The wave of investment in Internet infrastructure went beyond web sites available to

29. My own web site http://faculty-web.at.northwestern.edu/economics/gordon was developed by two undergraduate economics majors in the fall of 1998. 
Innovation, Demand, and Supply, Page 41

external customers. During the same period in the late 1990s, many business firms reorganized their internal communications systems as "intranets," web-based internal communication systems. Once the bugs were sorted out and these systems became operational, the investments had been made. Although computer manufacturers had become accustomed to a three-year replacement cycle in which old computers were routinely replaced by new computers, many firms currently view their late 1990s intranet investments as long-lasting and do not need to repeat the hardware or software purchases of the boom years. In the words of the Chief Information Officer of Mohawk Carpets, "We're not spending as much because we already spent it” (Thurm 2001).

\section{Legacy of the Failed Dotcoms}

Another pillar of the ICT investment boom of the late 1990s was the demand for computer hardware and software by the thousands of newly established e-commerce business firms collectively known as the dotcoms. Spurred by easily available finance from venture capitalists and IPOs, a booming economy, and overblown expectations, the "dotcoms" were touted as a new industrial revolution:

"The Internet has become a powerful symbol of society's expectations about the future-a future of fast-moving, disruptive technology that is shifting the terrain not only in business, but also in politics and culture. . . . Because it is such a low-cost communications technology, the Internet holds the promise of drastically reducing transactions costs. . . Organizational bureaucracies of every kind-corporate, government, and union-suddenly look vulnerable to the Internet's decentralizing powers" (Lohr 1999).

But the heralded dotcoms soon came crashing to the ground, leaving a legacy of failed 
Innovation, Demand, and Supply, Page 42

business models, not to mention a surfeit of unneeded computer hardware that soon flooded the market for used equipment, in turn bringing to a halt the previously rapid growth in the demand for new equipment. Some of the used equipment eventually found new users, but much of the software dedicated to the specific requirements of individual e-commerce web sites became instantly worthless.

An early virtue of e-commerce was the intense competition fostered by low costs of entry, pushing the economy toward the classroom model of perfect competition. But ecommerce firms soon learned that competition brings benefits to the consumer but leaves little if any residual in the form of operating profits. Thus much of the investment in computer hardware and software infrastructure for the dotcom boom ultimately had a zero or negative rate of return (as we suggested earlier in discussing the Oliner-Sichel productivity decomposition in Table 4). Further, the extent of reduction in transactions costs was exaggerated. For many products, ecommerce was just a new type of mail-order catalogue, providing an electronic interface for placing orders that eliminated the need for telephone operators, but no change in the technology of warehouses or delivery. As failed companies such as the e-grocer Webvan were soon to discover, the costs of the warehouses and delivery swamped the savings provided by the electronic order interface. ${ }^{30}$

If consumer e-commerce provided benefits to consumers without profits for dotcoms, then surely business e-commerce ("B2B") delivered benefits to businesses that flowed directly to

30. On the demise of Webvan see Spurgeon (2001). Among the problems cited, besides the costs of huge warehouses and truck fleets, were the reluctance of "busy people who have little time to sit home waiting for a delivery. .. the challenge remains being able to develop a large enough customer base to offset the costs of picking and delivering those groceries on a profitable basis." Further, time-pressed consumers chose not to turn to web delivery services but to buying prepared food in traditional supermarkets: "It turns out, however, that shopping isn't the step that busy consumers are eliminating. Cooking is." 
Innovation, Demand, and Supply, Page 43

the bottom line. Unfortunately B2B did not live up to its original promise; "many exchanges have shut down, and virtually all the rest are badly behind schedule in implementing their business plans" (Gomes 2001). What business firms need from their suppliers are "relationships, consistency, quality, and reliability" (Tedeschi 2001). For instance, a produce wholesaler had no use for produce Internet sites, because they lacked the element of trust that reassured customers that produce was fresh and top quality rather than rotting on the vine. Firms found that public ecommerce sites for buying supplies offered the same price to everyone, whereas firms had become used to developing individual relationships with suppliers and having price arrangements that were confidential. The produce wholesaler was quoted as rejecting the Internet for making public information that was previously confidential: "The Internet is very good at taking one message and sending it out to the whole world... That's not the way our world works" (Gomes 2001). Firms also were concerned about reliability and the chance that some B2B web sites would not remain in business, a fear that soon came to be realized. ${ }^{31}$

\section{Software Innovation is Falling behind Hardware Innovation}

Throughout the history of the computer industry, purchase and replacement decisions have been driven by the need to purchase new hardware in order to be able to operate increasingly complex software. Computer chip makers continually increased the speed and memory capability of computers, and hard drive manufacturers more than kept pace. ${ }^{32}$ But the

31. Ironically, the much heralded e-business technological revolution that was supposed to increase dramatically the efficiency of inventory management did not prevent one of the largest pile-ups of excess inventory in economic history, not only in ICT equipment but also in the economy as a whole, where inventory accumulation was negative for five straight quarters, 2001:Q1 to 2002:Q1.

32. My first PC in 1983 had a hard drive capacity of a mere 10MB. Today's standard 40GB hard drives represent an increase in capacity by a factor of 4,000 . Over the same period speed and memory have increased 
Innovation, Demand, and Supply, Page 44

minimum performance required to run the latest software also continued to increase, and users were continually under pressure to replace obsolescent machines with new ones capable of keeping up with software improvements. As the saying went, "What Intel giveth, Microsoft taketh away."

Perhaps the most controversial assertion of this paper is that this race is over, Intel has won, and Microsoft is lagging badly behind. Evidence keeps accumulating that computer users do not feel the same impetus to buy replacement computers as before, because improvements in software have ground nearly to a halt. Consider this comment by the dean of computer columnists, Walter Mossberg of the Wall Street Journal, in reflecting on the tenth anniversary of his column:

"The upgrade cycle in PC's has all but petered out. Back in 1991, we still lived in an era when people needed to buy the latest and greatest processors and other hardware, just to run all the new software. But it has been at least four years since software challenged hardware in that way. Today, the killer app is the Internet, and it doesn't require the fastest, biggest PCs. It only thirsts for faster connection speeds, greater bandwidth" (Mossberg 2001).

Mossberg is not alone in his assessment. Everyday, forecasts of slumping computer sales now routinely refer to the absence of compelling software: "Though PCs have grown more powerful, a lack of new software has dulled their shine for holiday sales. ... Consumers no longer are excited by faster processors running the same old programs" (McWilliams and Tam 2002). "Consumers and businesses have shown little inclination to shell out for new computers

somewhat less, by a factor of about 1,000 . This represents an annual rate of performance change of about 36 percent for speed and memory, and about 44 percent for hard drive capacity. 
Innovation, Demand, and Supply, Page 45

that do not offer significant improvements. ... After Windows 95 was released PCs have not changed so much." (Reuters 2002, p C3). ${ }^{33}$ Other computer columnists concur: "There are many reasons for the current slump in personal computer sales, but one of the most important is the lack of software that gives us a compelling reason to replace our machines" (Wildstrom 2001).

Simple increases in computer speed and memory are not enough: "Even personal computer industry veterans acknowledge the paucity of new ideas that currently troubles the computer industry. ... computers have reached a point where for the most common home purposes - Web surfing, e-mail, and word processing — they are already more than fast enough to suit a typical home user's needs. As long as new PC's are just faster, cheaper, better than old PC's, you're going to get slow growth" (Markoff 2002).

The lack of compelling new types of software has translated into a stalling out of the advance of computer penetration in the American home. After growing from 30 to 60 percent between 1995 and 2001, the share of households with PCs remained unchanged at 60 percent in 2002. Worse yet, the reason most holdouts gave for not owning a computer at home was not price or technological ignorance, but that they "just had no compelling reasons to own PCs" (Gaither 2002). Part of the problem may be that the initial novelty of the web has worn off for early users, while current non-users are not persuaded to access the web. Another issue is the very source of the demise of many early dotcom firms: they could not figure out how to make a profit. The web now teems with advertising and user fees, repelling some early users:

33. Article from Reuters with no author listed, "PC sales fail to rev up as school starts," Chicago Tribune, September 9, 2002, p. C3. 


\section{Innovation, Demand, and Supply, Page 46}

"Everywhere you go someone is jumping on you to buy something. ... It's like walking down the streets of Tijuana." For some users the novelty value of the web has started to wear off: "I'm a frontiersperson, and the Web is not a frontier anymore... . It is simply a place" (both quotes from Guernsey 2002).

To be sure, some computer users always value more speed and memory, especially those whose main uses are games and the downloading of photos, video, and audio. But we are primarily interested in business rather than consumer uses of computers, since business uses are presumably those that contribute to productivity growth in the private business economy. Consumer use of computers for games, video, and audio may raise consumer welfare, but not in a way that increases measured output per hour. And it is in the business world where the shift in attitudes about computer enhancement and replacement is most profound. As one corporate Chief Information Officer stated, "There is no commercial incentive to upgrade computers anymore. The hardware and software guys know it, and they are desperate about it." The CIO previously upgraded his 15,000 PCs every two or three years, but now says that he will do the next big overhall "in a few years, maybe" (both quotes from Hardy, 2002).

\section{Y2K Compressed the Replacement Cycle}

The final, and probably least important, of the factors that temporarily boosted the demand for computers in the late 1990s was the much-publicized potential crisis regarding the inability of existing software, primarily older versions of programs written before the mid-1990s, to handle the transition from years beginning in "19XX" to "20XX." An enormous investment in software reprogramming occurred throughout 1998 and 1999 at almost every corporation, large and small. Some unknown part of the rapid growth of real computer investment displayed 
Innovation, Demand, and Supply, Page 47

above in Figure 2 above was related to the $\mathrm{Y} 2 \mathrm{~K}$ phenomenon, and particularly the compression of the normal replacement cycle as computers scheduled for normal replacement in 2000 and 2001 were instead replaced in 1998 and 1999.

\section{Is Broadband the Answer?}

If anything can stimulate purchases of ICT equipment in the next few years, it is the adoption of broadband in every American household that currently accesses the internet via slow dial-up connections. An immediate qualification is that American corporate business already has fast connections, and even college freshmen have lightning-fast access to the internet from their

dorm rooms. Whatever impact on business productivity made possible by universal adoption of broadband in the American corporate and institutional world has already occurred. A rush to install broadband connections in the American household would not have a direct impact on business productivity, since its major effect would be to allow faster downloading of video, music, and games.

But American households are not rushing to convert to broadband. In early 2002 adoption rates for all types of broadband was below 10 percent and was not rising at the rate that had been expected. Noam (2002) provides three reasons. First, broadband is not free, and it costs substantially more to provide than ordinary dial-up on an existing residential telephone line. Second, the network effects that multiply the benefits of an invention like e-mail when it is universally adopted do not apply to broadband, since if Uncle Harry switches from dial-up to broadband, it has no effect on the benefits to Cousin Sarah of dialing up to send an e-mail to Uncle Harry. Third is "the absence of a strong reason to have it. ... There is only so much free time and attention to go around in a day, and there is no indication that broadband users use the 
Innovation, Demand, and Supply, Page 48

Internet much differently than narrowband users.... we must push the demand side of broadband to catch up with the supply" (Noam, 2002, p. 4, p. 9).

\section{Conclusion}

Many studies have linked the post-1995 productivity growth revival in the United States to the acceleration in the growth of ICT investment that occurred at the same time. At first glance, their link between productivity and ICT would seem to imply that the revival had a single source-ICT investment—achieved both through its production and use. An acceleration in the growth of real investment in computers made possible more rapid MFP growth in the production of computers, as well as a greater contribution to productivity growth through capital deepening as the rest of the economy purchased and used the new, more powerful computers.

This paper brings both bad news and good news to the debate over the role of ICT capital and the future outlook for productivity growth. The bad news, and the main contribution of the paper, is that the ICT investment boom of the late 1990s was inherently transitory and unsustainable for both macroeconomic and microeconomic reasons. The growth rate of ICT investment did not occur in isolation but was supported by a positive feedback loop among an unusual confluence of positive macroeconomic shocks, including the stock market boom, a set of beneficial supply shocks that reduced inflation, and the role of low inflation in creating the benign tolerance by the Federal Reserve of unusually rapid output growth and a decline in the unemployment rate without precedent in the preceding three decades. At the same time, the growth rate of ICT investment was supported by a set of transitory microeconomic sources of demand for ICT equipment, including the telecom investment bubble, the fact that the World 
Innovation, Demand, and Supply, Page 49

Wide Web could be invented only once, the equipment and software purchases by the dotcoms that promptly failed, and the last gasp of Microsoft and other software makers as they struggled to find ways for firms and consumers to use the explosion in the growth of computer power made possible by the inexorable advance of Moore's Law.

The good news is that a failure of ICT investment growth to return to the heady days of the late 1990s does not doom productivity growth to return to the dismal decades prior to 1995 . The best recent work on the sources of the productivity revival between 1995 and 2001 attributes all of this revival to the growth acceleration in ICT investment. Taken literally, this work implies that if the growth rate of ICT investment falls back to its pre-1995 pace, productivity growth will likewise return to its pre-1995 rate. But it is possible that this recent research overstates, perhaps substantially, the contribution of ICT investment to the productivity revival. Recent writing on productivity growth points to retail trade as a key locus of the role of computers in creating productivity growth, reasoning that retailing is an industry that both uses ICT equipment heavily and displays a robust productivity growth revival at the level of industry data.

But much more has been going on in the retail sector, and presumably in other industrial sectors that are heavy users of ICT equipment, than just buying lots of computers and software. Micro evidence at the level of individual establishments shows that all of the productivity growth in the retail sector in the 1990s was achieved by new establishments, and that none of it was achieved by establishments already existing in 1990, no matter how many computers they bought. This suggests that a central role in the productivity growth revival of the 1990s was a set of non-ICT investments and organizational innovations that we associate with "big box" retailers 


\section{Innovation, Demand, and Supply, Page 50}

like Wal-Mart, Home Depot, Best Buy, and others. Old establishments checked out their customers with bar coder scanners, just as did new establishments, but ICT investments were apparently "necessary but not sufficient" for retail productivity to increase. A complementary finding is that much of the failure of Europe to achieve its own productivity growth revival in the late 1990s can be traced to the same industries that performed so well in the United States, particularly retail and wholesale trade and the securities industry.

The confluence of the bad news and good news leaves the future of productivity growth highly uncertain. The macro and micro foundations of the late 1990s ICT investment boom may not reappear in our lifetimes, and it may be decades before we see five straight years of annual growth rates of ICT investment of greater than 30 percent per year. But the role of ICT investment as a foundation of the productivity growth revival has been exaggerated, leaving other kinds of investment and organizational improvements playing a role that has not been sufficiently appreciated. This conclusion, albeit not susceptible to quantification, has one fortunate byproduct -- it helps us understand why Europe failed to duplicate the U. S. productivity revival despite using the same computer hardware and software as Americans did. Europe's troubles lie elsewhere and cannot be solved by purchasing more computers. The environment of product and labor market regulation in Europe still, despite recent improvements, inhibits the bold new types of retailing formats that formed the vanguard of the U. S. productivity revival. Whether Europe can loosen its straightjacket of regulations, and whether the U. S. can sustain these organizational improvements in the absence of a new ICT investment boom, remain as unanswered questions. 
Innovation, Demand, and Supply, Page 51

\section{REFERENCES}

Bartlesman, E. et al. 2002. "The Spread of ICT and Productivity Growth: Is Europe Really Lagging Behind in the New Economy," OECD draft report presented at Conference "The Information Economy: Productivity Gains and the Digital Divide," Catania, Sicily, June 15.

Berman, D. K. 2002. "Innovation Outpaced the Marketplace," Wall Street Journal, September 26, p B1.

Blanchard, O., and J. Simon. 2001. "The Long and Large Decline in U.S. Output Volatility," Brookings Papers on Economic Activity 32(1): 135-164.

Brynjolfsson, E. 1996. "The Contribution of Information Technology to Consumer Welfare," Information Systems Research 7(3): 281-300.

David, Paul A. (1990). "The Dynamo and the Computer: An Historical Perspective on the Modern Productivity Paradox," American Economic Review (Papers and Proceedings) 80(2): 355-361.

Daveri, Francesco, and Mascotto, Andrea (2002). "The IT Revolution across the U. S. States," University of Parma and Bocconi University working paper, November 5.

Dreazen, Y. J. 2002. "Behind the Fiber Glut,” Wall Street Journal, September 26, p B1.

Foster, Lucia, John Haltiwanger, C.J. Krizan, "The Link Between Aggregate and Micro Productivity Growth: Evidence from Retail Trade" NBER Working Paper No. 9120, August 2002.

Gaither, C. 2002. "The Many, the Skeptical, the Folks Without PC's," The New York Times, March 18, p C3.

Gomes, L. 2001. "How Lower-Tech Gear Beat Web Exchanges at Their Own Game," Wall Street Journal, March 16, p A1.

Gordon, R. J. 1977. “Can the Inflation of the 1970s Be Explained?" BPEA 1:1977[MSOffice70], 253-277. 1982. "Inflation, Flexible Exchange Rates, and the Natural Rate of Unemployment." In 
Innovation, Demand, and Supply, Page 52

M. N. Baily, ed., Workers, Jobs, and Inflation. Washington, DC: Brookings. 1990. The Measurement of Durable Goods Prices. Chicago: University of Chicago Press.

1993. "The Jobless Recovery: Does It Signal a New Era of Productivity-Led Growth?" Brookings Papers on Economic Activity 24(1): 271-316.

- 1997. "The Time-Varying NAIRU and its Implications for Economic Policy." Journal of Economic Perspectives 11(1): 11-32.

. 1998. "Foundations of the Goldilocks Economy: Supply Shocks and the Time-Varying NAIRU," Brookings Papers on Economic Activity 29(2): 297-333.

- 2000. "Does the New Economy Measure Up to the Great Inventions of the Past?" Journal of Economic Perspectives 14(4): 49-74.

Guernsey, L. 2002. "As the Web Matures, Fun Is Hard to Find," The New York Times, March 28, p D1.

Griliches, Z. 1994. "Productivity, R\&D, and the Data Constraint," American Economic Review 84(March): 1-23.

Hardy, Quentin (2002). “The Customer’s Revenge,” Forbes, October 28, pp. 118-24.

Hodrick, R., and E. C. Prescott. 1981. "Postwar U.S. Business Cycles: An Empirical Investigation.” Discussion Paper No. 451. Minneapolis, MN: University of Minnesota (May).

Hultgren, T. 1960. "Changes in Labor Cost during Cycles in Production and Business." NBER [MSOffice71]Occasional Paper 74. New York: National Bureau of Economic Research.

Jorgenson, D. W. 2001. "Information Technology and the U.S. Economy," American Economic Review 91(1): 1-32.

-2002. Economic Growth in the Information Age: Econometrics. Vol. 3. Cambridge MA: MIT Press.

Jorgenson, D. W. [MSOffice72]and K. J. Stiroh.2000. "Raising the Speed Limit: U.S. Economic Growth in the Information Age," Brookings Papers on Economic Activity 31(1): 125-211.

Lex (2001). “Technical Difficulties,” Financial Times, April 18, p. 18.

Lohr, S. 1999. "The Economy Transformed, Bit by Bit," The New York Times, December 20, p 
Innovation, Demand, and Supply, Page 53

C1.

Markoff, J. 2002. "PC Makers Hit Speed Bumps; Being Faster May Not Matter," The New York Times, September 30, p C1.

McWilliams, G., and P.-W. [MSOffice73]Tam. 2002. "Season Looks Gloomy for PCs," Wall Street Journal, October 17, p B4.

Miller, R. 2001. “Too Much of Everything,” Business Week, April 9: 28-30.

Mossberg, W. 2001. “Decade Yields Dramatic Progress in Personal Technology,” Wall Street Journal, October 25, p B1.

The New York Times. "Small Employers Severely Cut Health Care," The New York Times, September 6, 2002, p C4.[MSOffice74]

Noam, Eli (2002). Panel presentation in "Broadband: Opportunities and Challenges for the Telecommunications Industry," transcript of a Forum presented by the Economic Strategy Institute. Washington, D. C., Economic Strategy Institute, pp. 1-9.

Nordhaus, W. D. 2002a. "The Recent Recession, the Current Recovery, and Stock Prices," Brookings Papers on Economic Activity 33(1): 199-220.

- 2002b. "Productivity Growth and the New Economy," Brookings Papers on Economic Activity 33(2): forthcoming.

Okun, A. M. 1962. "The Gap between Actual and Potential Output," Proceedings of the American Statistical Association, reprinted in Edmund S. Phelps, ed., Problems of the Modern Economy. New York: Norton, 1965.

Oliner, S. D. and D. E. Sichel. 2000. "The Resurgence of Growth in the Late 1990s: Is Information Technology the Story?" Journal of Economic Perspectives 14(Fall): 3-22.

— 2001. "The Resurgence of Growth in the Late 1990s: Is Information Technology the Story?" Updated presentation presented at the meetings of the American Economic Association, January 7.

- 2002. "Information Technology and Productivity: Where Are We Now and Where Are We Going?" Atlanta Federal Reserve Bank Review (forthcoming).

Reuters. 2002. "PC Sales Fail to Rev Up as School Starts," Chicago Tribune, September 9, p. C3.

Sichel, D. E. 1997. The Computer Revolution: An Economic Perspective. Washington, DC: 


\section{Brookings.}

Sieling, M., B. Friedman, and M. Dumas. 2001. "Labor Productivity in the Retail Trade Industry, 1987-99," Monthly Labor Review (December): 3-14.

Spurgeon, D. 2001. “Traditional Grocers Feel Vindicated by Webvan's Failure,” Wall Street Journal, July 12, p B3.

Tedeschi, B. 2001. "E-commerce Report,” The New York Times, March 5, p C11.

Thurm, S. 2001. "The Broader Slowdown Isn't the Only Cause of Tech Industry's Ills," Wall Street Journal, March 21, p A1.

Triplett, J. E. and B. P. Bosworth. 2002. "Baumol's Disease Has Been Cured: IT and Multifactor Productivity in U.S. Services Industries," Paper [MSOffice75]presented at Brookings Workshop on Services Industry Productivity, Washington, D. C., May 17.[MSOffice76]

van Ark, B. , R. Inklaar, and R. H. McGuckin 2002. "Changing Gear: Productivity, ICT and Service Industries: Europe and the United States," paper presented to Brookings Workshop on Services Industry Productivity, May 17.[MSOffice77]

Wildstrom, Stephen H. (2001). "Buying a New PC? Not So Fast," Business Week, April 2, p. 26.

Yang, Catherine (2002). "The Decision that could Reshape Telecom," Business Week, September 30, p. 86. 
Figure 1

Output per Hour in the Nonfarm Private Business Sector, Actual Change from Four Quarters Prior and Hodrick-Prescott Trend, 1960-2002, Percentage Changes at Annual Rate

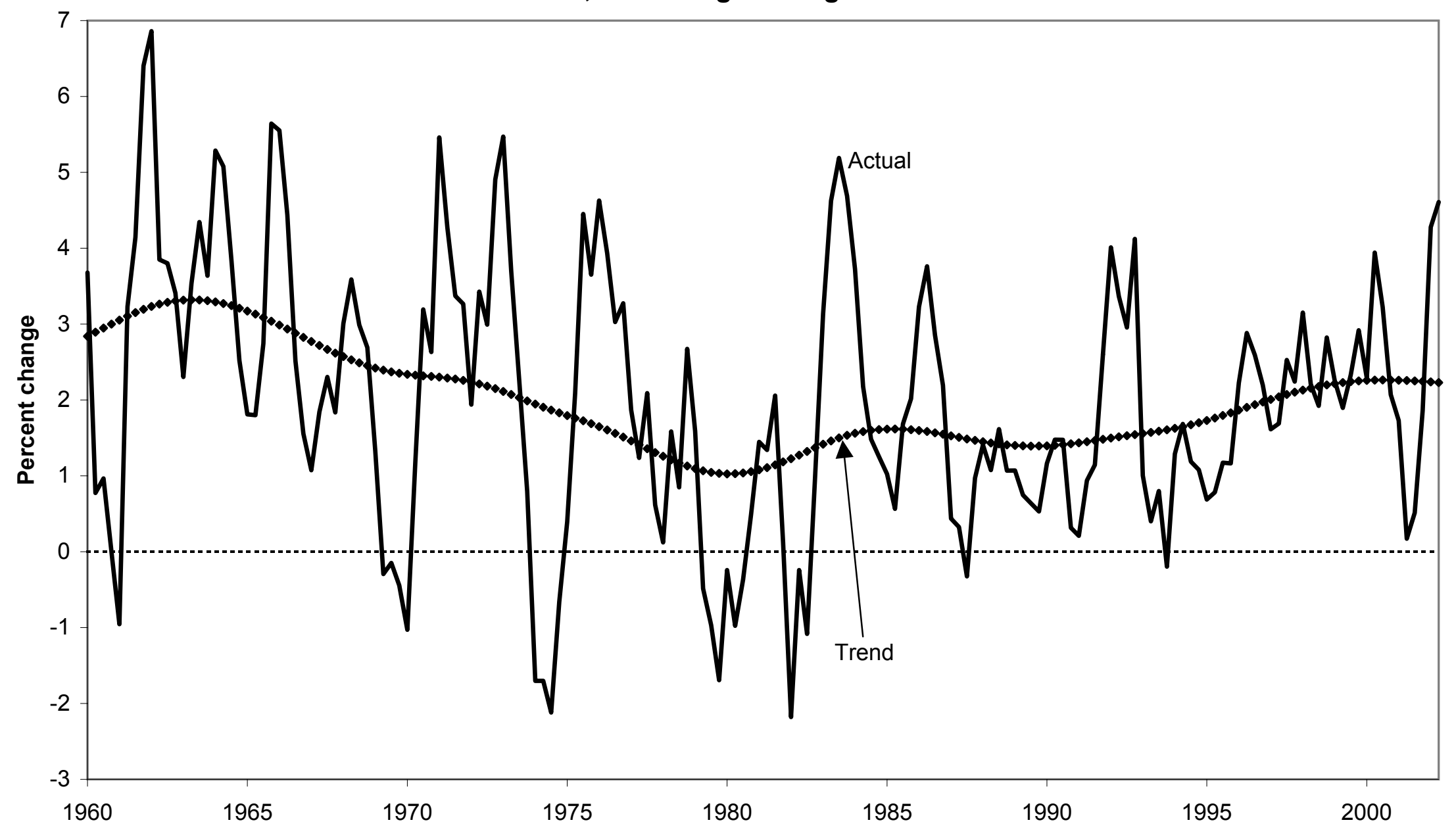


Figure 2

Real Investment in Computers and Peripherals and its Deflator, Change from Four Quarters Prior, 1987-2002,

Percentage Changes at an Annual Rate

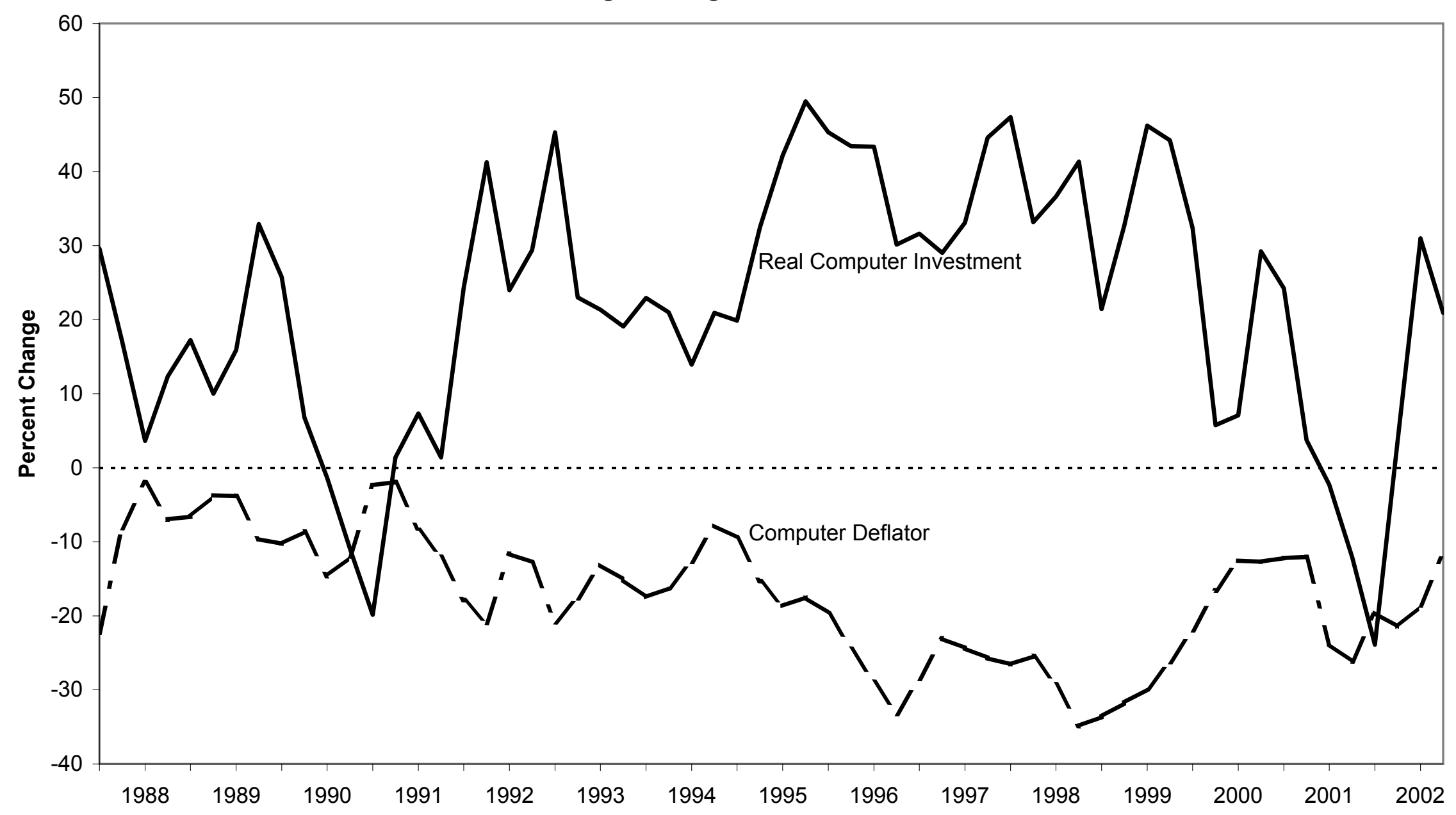


Figure 3

Ratio to Nominal GDP of Nominal Investment in Computers and Peripherals, Quarterly data, 1960-2002

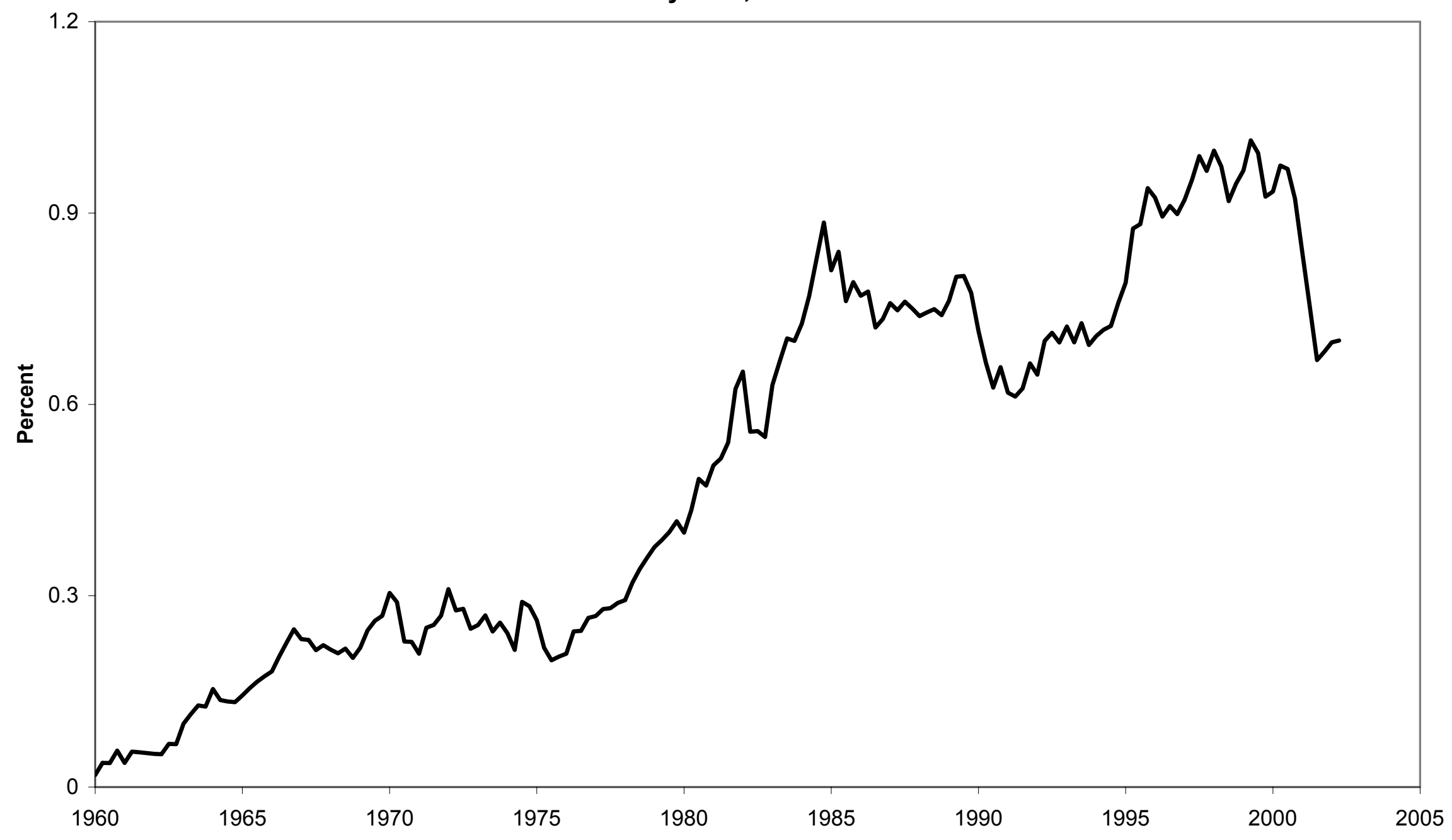


Figure 4

Ratio to Nominal GDP of Nominal Investment in Information Technology,

Quarterly data, 1960-2002

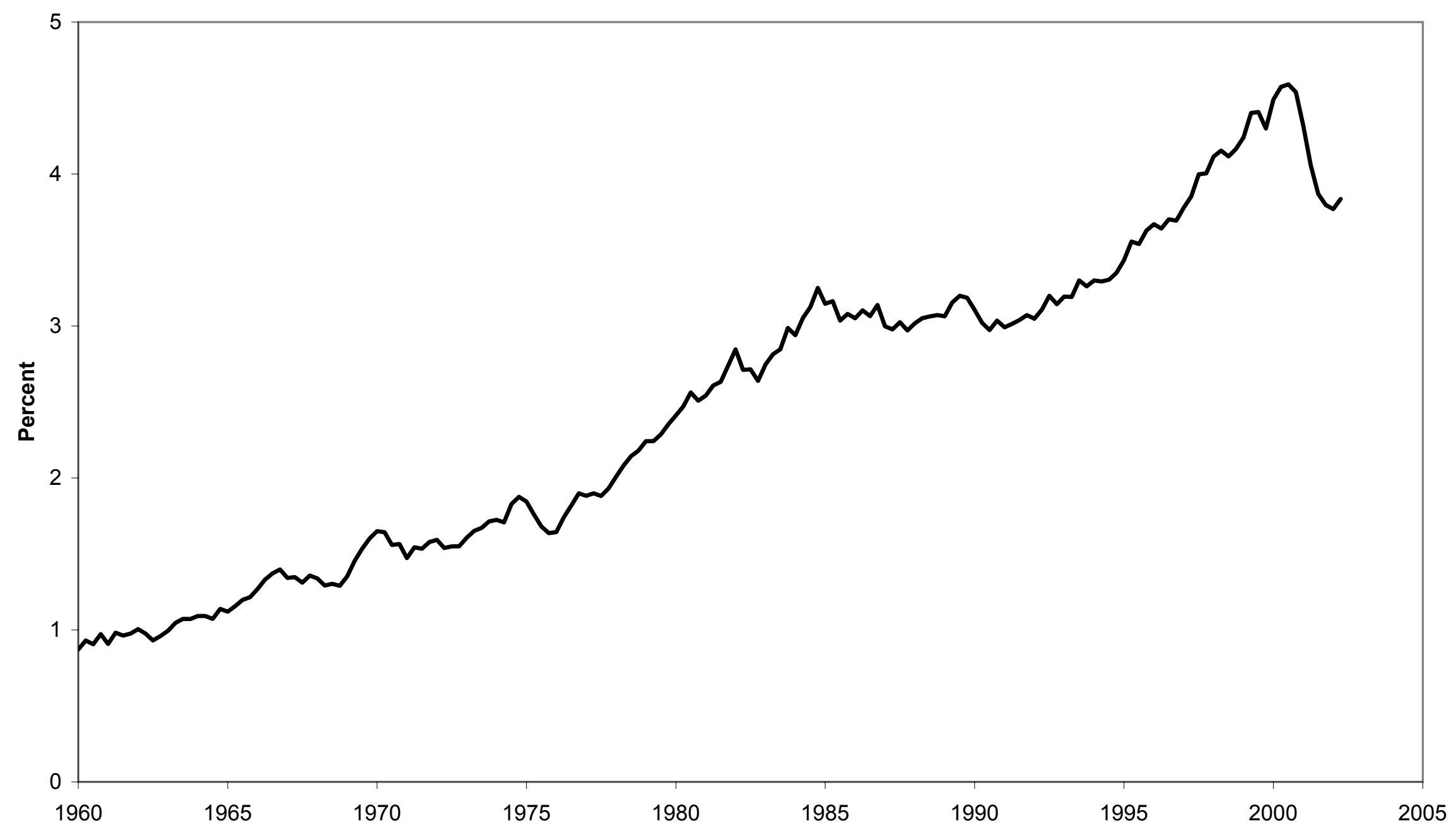


Figure 5

Household Saving Rate and Ratio of S\&P500 Stock Market Index to Nominal GDP, 1972=100, Annual data, 1970-2002

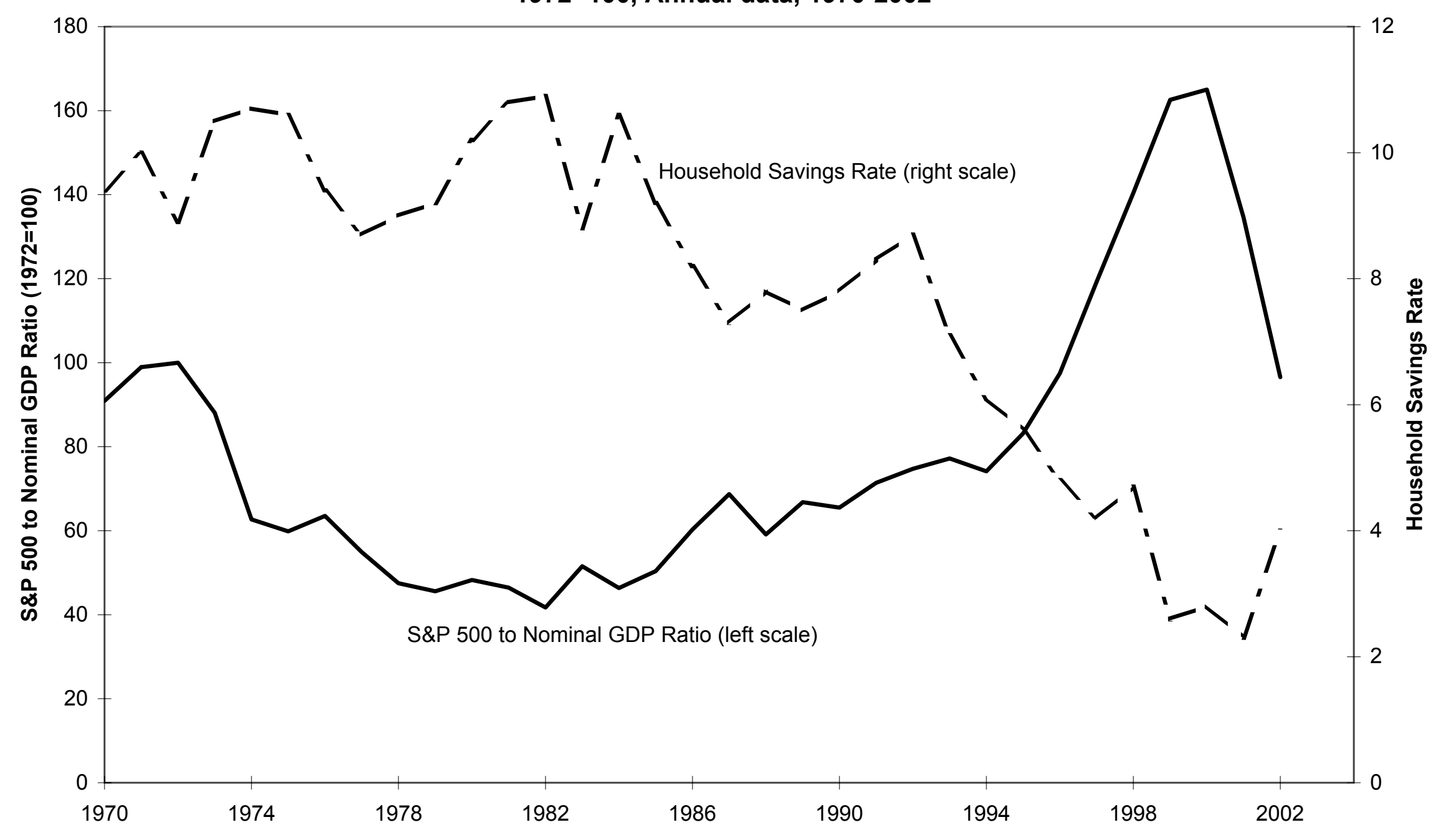


Figure 6

The Unemployment Rate and the Change from Four Quarters Prior of the Deflator for Personal Consumption Expenditures, Quarterly Data, 1960-2002

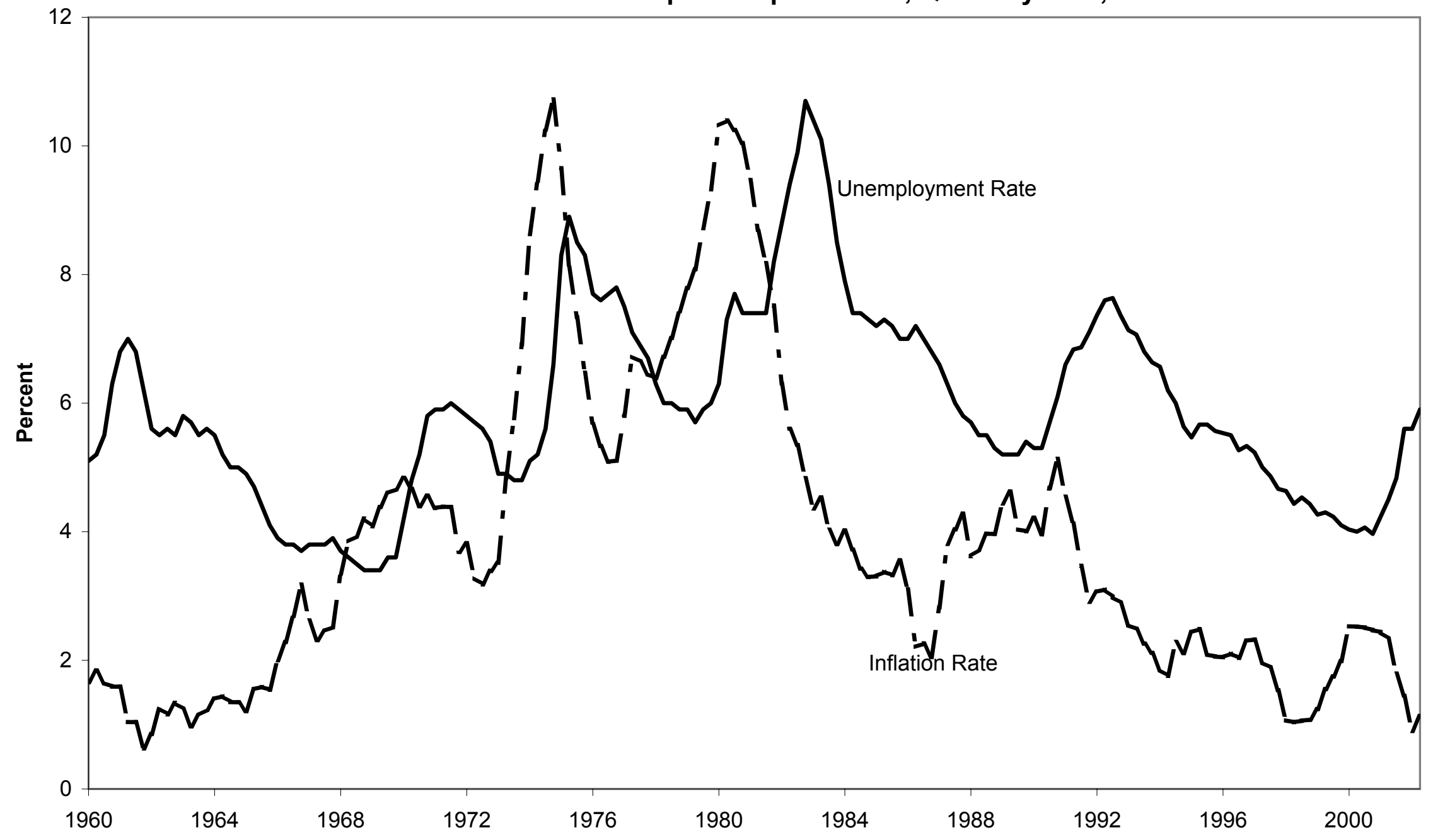


Figure 7

The Federal Funds rate and the Log Ratio of Actual to Natural Real GDP,

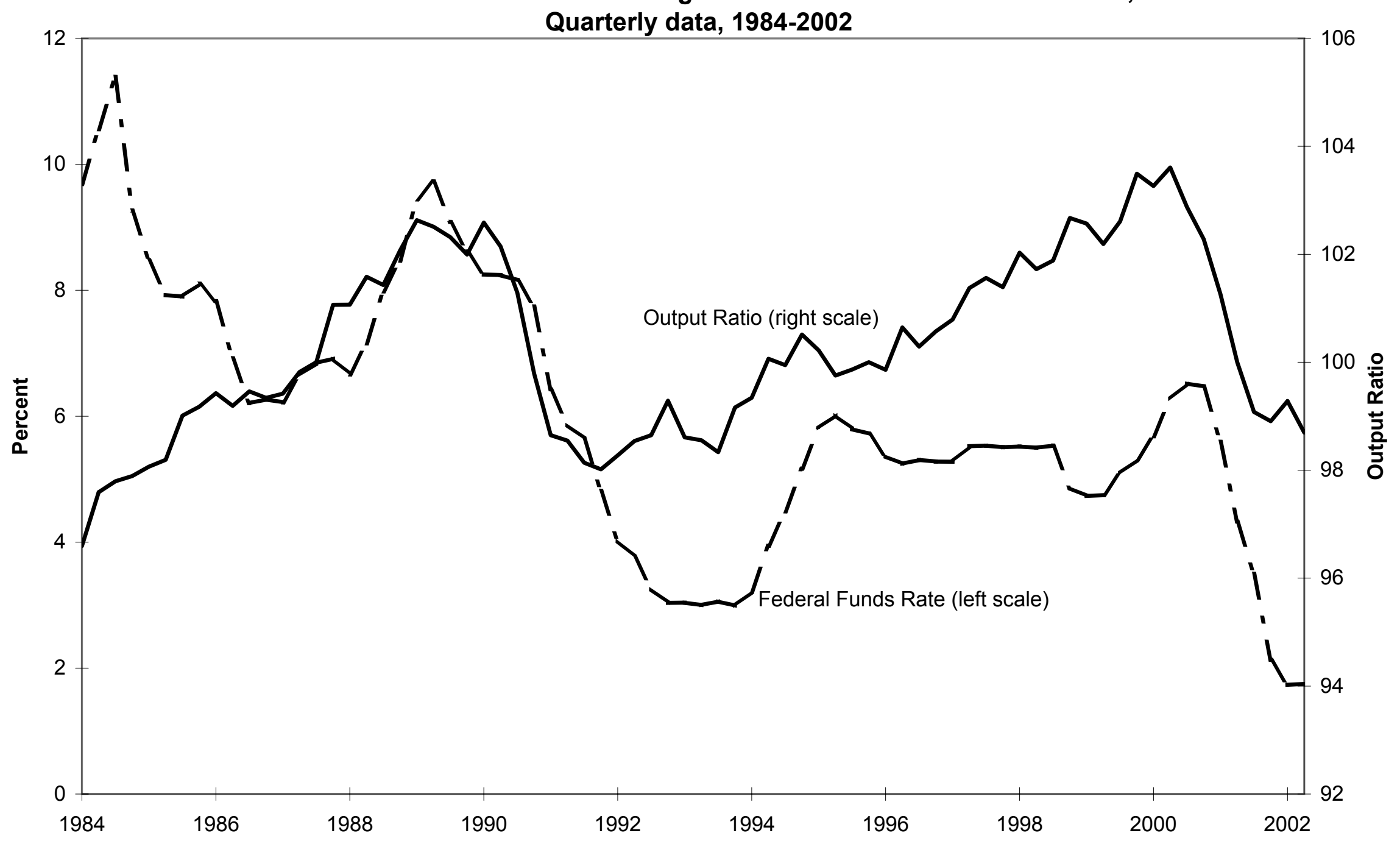




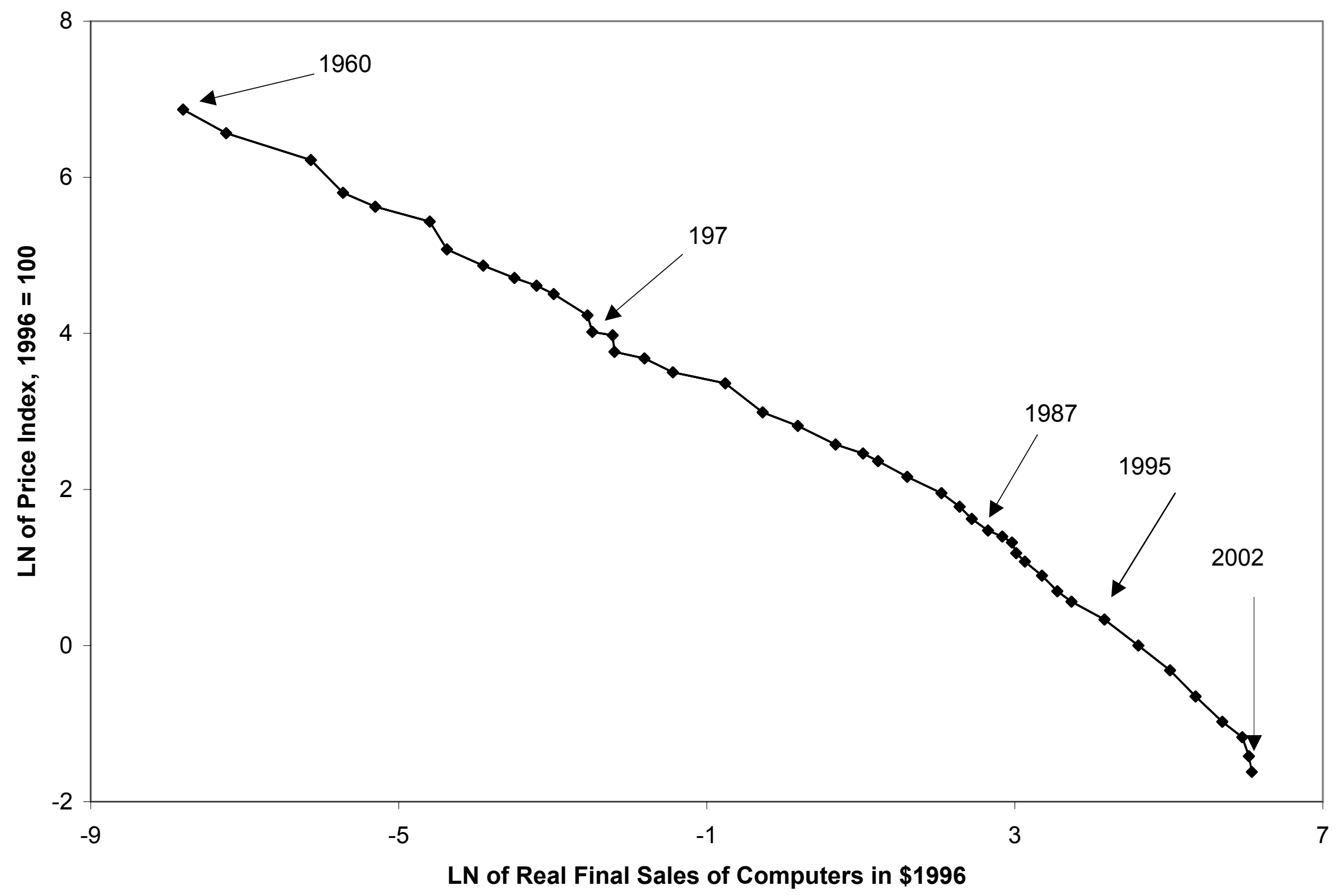




\section{Table 1}

Annual Growth Rates of Output per Hour, 1950-2002,

Selected Sectors and Intervals, in Percent

\begin{tabular}{|c|c|c|c|c|c|c|}
\hline Sector & $\begin{array}{l}\text { 1950:Q2- } \\
\text { 1972:Q2 }\end{array}$ & $\begin{array}{l}\text { 1972:Q2- } \\
\text { 1995:Q4 }\end{array}$ & $\begin{array}{l}\text { 1995:Q4- } \\
\text { 2002:Q2 }\end{array}$ & $\begin{array}{l}\text { 1995Q4- } \\
\text { 2000Q2 }\end{array}$ & $\begin{array}{l}\text { 2000Q2- } \\
\text { 2001Q3 }\end{array}$ & $\begin{array}{l}\text { 2001Q3- } \\
\text { 2002Q2 }\end{array}$ \\
\hline Nonfarm Private Business & 2.66 & 1.42 & 2.53 & 2.59 & 0.68 & 5.46 \\
\hline Manufacturing & 2.56 & 2.60 & 3.95 & 4.47 & 1.11 & 5.93 \\
\hline Durables & 2.34 & 3.05 & 4.94 & 5.94 & 0.07 & 7.09 \\
\hline Nondurables & 2.97 & 1.95 & 2.85 & 2.94 & 2.11 & 4.22 \\
\hline Nonfarm Nonmanufacturing & 2.64 & 1.00 & 2.05 & 2.04 & 0.98 & 5.31 \\
\hline
\end{tabular}


Table 2

Growth Rates of Output per Hour, Nonfarm Private Business Sector, Selected Intervals, 1955-2002

\begin{tabular}{lrrr}
\hline Interval & \multicolumn{1}{c}{$\begin{array}{c}\text { Actual } \\
\text { Growth }\end{array}$} & $\begin{array}{l}\text { Trend } \\
\text { Growth }\end{array}$ & $\begin{array}{l}\text { Cyclical } \\
\text { Effect }\end{array}$ \\
\hline \hline & & & \\
1955:Q4-1965:Q4 & 2.99 & 2.90 & 0.09 \\
1965:Q4-1975:Q4 & 2.02 & 2.25 & -0.23 \\
1975:Q4-1985:Q4 & 1.44 & 1.33 & 0.11 \\
1985:Q4-1995:Q4 & 1.39 & 1.54 & -0.15 \\
& & & \\
& & & \\
$1995: Q 4-2000: Q 2$ & 2.59 & 2.15 & 0.44 \\
2000:Q2-2001:Q3 & 0.68 & 2.25 & -1.57 \\
2001:Q3-2002:Q2 & 5.46 & 2.22 & 3.24 \\
\hline
\end{tabular}

Sources: Actual growth from Bureau of Labor Statistics, trend growth estimed as a Hodrick-Prescott filter with a smoothing parameter of 6400 . The same series is plotted in Figure 1. 


\section{Table 3}

Growth Rates of Output per Hour, Nonfarm Private Business Sector, Four Quarters at Start of Recovery and Next Eight Quarters

\begin{tabular}{lcc}
\hline Interval & $\begin{array}{c}\text { Initial Four } \\
\text { Quarters }\end{array}$ & \multicolumn{2}{c}{$\begin{array}{l}\text { Next Eight } \\
\text { Quarters }\end{array}$} \\
\hline \hline & & \\
$1975: Q 1-1976: Q 1$ & 4.63 & 0.99 \\
$1982: Q 3-1983: Q 3$ & 5.19 & 1.58 \\
$1991: Q 1-1992: Q 1$ & 4.01 & 1.15 \\
$2001: Q 3-2002: Q 2$ & 5.46 & $? ? ?$ \\
\hline
\end{tabular}

Source: Bureau of Labor Statistics 


\section{Table 4}

Contributions to Growth in Labor Productivity by Source 1973-95 vs. 1995-2001 and post-1995 Growth Acceleration

\begin{tabular}{|c|c|c|c|}
\hline & $\begin{array}{l}1973- \\
1995 \\
\end{array}$ & $\begin{array}{l}1995- \\
2001 \\
\end{array}$ & $\begin{array}{c}\text { Post-1995 } \\
\text { Change }\end{array}$ \\
\hline Labor Productivity & 1.40 & 2.25 & 0.85 \\
\hline \multicolumn{4}{|l|}{ Contributions from: } \\
\hline Capital Deepening & 0.71 & 1.17 & 0.46 \\
\hline Information Technology Capital & 0.42 & 0.97 & 0.55 \\
\hline Other Capital & 0.30 & 0.20 & -0.10 \\
\hline Labor Quality & 0.27 & 0.25 & -0.02 \\
\hline Multifactor Productivity & 0.42 & 0.83 & 0.41 \\
\hline Information Technology Capital & 0.30 & 0.73 & 0.43 \\
\hline Other Sectors & 0.12 & 0.10 & -0.02 \\
\hline Memo: Total IT Contribution & 0.72 & 1.70 & 0.98 \\
\hline
\end{tabular}

Source: Unpublished update to Oliner and Sichel (2002), provided by the authors. 


\section{Table 5}

Labor Productivity by Industry Group, U. S. vs. Europe, $1990-95$ vs. $1995-2000$, Annual Growth Rates in Percent

\begin{tabular}{lcccccc}
\hline & \multicolumn{3}{c}{ United States } & & \multicolumn{2}{c}{ European Union } \\
\cline { 2 - 4 } \cline { 5 - 6 } & $\begin{array}{c}1990- \\
1995\end{array}$ & $\begin{array}{c}1995- \\
2000\end{array}$ & & $\begin{array}{c}1990- \\
1995\end{array}$ & $\begin{array}{c}1995- \\
2000\end{array}$ \\
\hline \hline Total Economy & 1.1 & 2.2 & & 2.4 & 1.5 \\
ICT Producing Industries & 6.1 & 6.5 & & 6.0 & 8.5 \\
ICT Using Industries & 1.4 & 4.2 & & 1.9 & 1.3 \\
Non-ICT Industries & 0.4 & 0.4 & & 2.4 & 1.0 \\
& & & & & & \\
\hline
\end{tabular}

Source: van Ark et. Al. (2002, Table 5). 